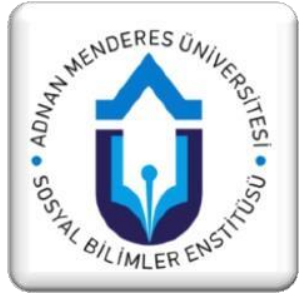

Makale Geçmiși

Başvuru Tarihi:12.04.2021

Kabul Tarihi:07.05.2021

\section{Sosyal Hizmet Perspektifinden Göç ve Savunmasız Gruplar: IOM Raporları Üzerine Bir Araştırma}

\author{
Mustafa KARATAŞ ${ }^{1,}$ Berçem BARUT $^{2}$
}

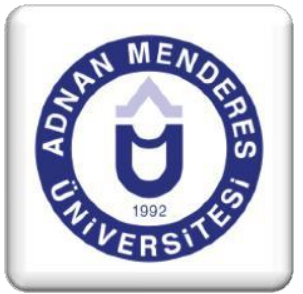

Article History

Date of Application:12.04.2021

Acceptance Date:07.05.2021

\title{
Özet
}

Küreselleşme, neoliberal politikalar, savaşlar, bölgesel çatışmalar ve teknolojik gelişmeler bireylerin ve grupların bulundukları yerlerden göç etmesine neden olabilmektedir. Göç hareketliliği olarak adlandırılan bu süreçler birçok dinamik barındırmakta ve bu dinamiklerin önemli bir kısmı ise göçün özneleri için risk ve tehdit unsuru olarak karşımıza çıkmaktadır. Göçün farklı evrelerinde karşılaşılan güçlükler, göç eden bireyleri savunmasız kılmakta ve iyilik hallerini doğrudan etkilemektedir. Sosyal hizmetin bireylerin iyilik halini ve işlevselliğini arttırma amacı, göçmenlerin savunmasızlıklarını tanımlamayı, ihtiyaçlarının tespitini ve değerlendirilmesini gerekli kılmaktadır. Araştırmada Uluslararası Göç Örgütü (IOM) tarafından son on yıl içerisinde hazırlanan altı rapor incelenmiş ve veriler MAXQDA 2020 programı ile analiz edilmiştir. Araştırma savunmasız gruplara yönelik sosyal politikalara ve sosyal hizmet müdahalelerine yönelik bilgi paylaşımını ve göç alanındaki uygulayıcılara birtakım önerileri ortaya koyarak, mesleğin bilgi temeline katkı sunmayı amaçlamıştır.

Anahtar Kelimeler: Göç, göçmenler, IOM, savunmasız gruplar, sosyal hizmet

\section{Migration And Vulnerable Groups From Social Work Perspective: A Study On IOM Reports}

\begin{abstract}
Globalization, neoliberal policies, wars, regional conflicts, and technological developments cause individuals and groups to migrate from their places. These processes, called migration mobility, contain many dynamics, and a significant part of them is a risk and threat to the subjects of migration. Difficulties encountered at different stages of migration make migrants particularly vulnerable and directly affect their well-being. The aim of social works to increase the well-being and functionality of individuals require to defining the vulnerabilities of immigrants, identify as well as evaluate their needs. The study aimed to examine six reports prepared by the International Organization for Migration (IOM) in the last ten years and the data was analyzed with the MAXQDA 2020 program. The search intended to share some analyses on social policies and social work interventions for vulnerable groups and to contribute to the knowledge base of the profession by making a number of recommendations to practitioners in the field of migration.
\end{abstract}

Keywords: Migration, immigrants, vulnerable groups, IOM, social work

\footnotetext{
${ }^{1}$ Dr. Öğretim Üyesi, İstanbul Sabahattin Zaim Üniversitesi, Sağlık Bilimleri Fakültesi, Sosyal Hizmet Bölümü, ORCID Numaras1: 0000-0002-0998-2552

2 Öğretim Görevlisi, Çorum Hitit Üniversitesi, Sosyal Bilimler Yüksekokulu, Sosyal Hizmet ve Danışmanlık Bölümü, ORCID Numaras1: 0000-0002-9134-9456
} 


\section{Giris}

Küreselleşme, bölgesel istikrarsılılklar ve çatışmalar bireylerin daha iyi bir yaşam sürebilecekleri yerleşim alanları arayışına girmelerine, ülkeleri içinde ya da başka güvenli bir ülkeye göç hareketlerine neden olmaktadır. Göç sonrasında, özellikle göç alan ülkelerde, etkili ve programlı göç yönetiminin yapılması için yasal düzenlemeler ve ulusal programlar gerçekleştirilmektedir. Ülke programlarının ve düzenlemelerinin yanı sıra sivil toplum kuruluşlarının da ulusal ölçekte ve sınır ötesinde çalışmalar yürüttüŭü bilinmektedir.

Özellikle uluslararası göç hareketi gerçekleştirenlerin, menşe ülkelerinden geçici olarak kendilerini güvende hissedecekleri ve temel insani ihtiyaçlarını karşılayacakları transit ülkelere, oradan da yaşamlarını devam ettirebilmek için son durakları olan hedef ülkelere göç ettikleri bilinmektedir. Ancak çeşitli evrelerden oluşan göç yolculuğu, bazı aşamalarında maruz kalınabilecek risk ve tehditler içermektedir. Bu risk ve tehditlere bağlı olarak birey, aile ve grup düzeyinde mağduriyetler yaşanmaktadır. $\mathrm{UNICEF}^{2}$ verilerine göre zorla ülkelerinden edilen yaklaşık 29 milyon mülteci ve sığınmacı bulunmaktadır. 2018 yılında çatışma ve şiddet nedeniyle ülkeleri içinde yerinden edilen, 17 milyonu çocuk yaklaşık 41 milyon göçmen varken, 2019 yılında uluslararası göçmen sayısı 33 milyonu çocuk olmak üzere 272 milyona ulaşmıştır.

Göç olgusu birey, aile, grup ve toplulukların çeşitli nedenlerle mekânsal hareketlilik süreçlerine dahil olması bakımından karmaşık bir süreçtir. Bireylerin gönüllü ya da gönülsüz olarak yerini değiştirmeye karar vermesi ile başlayan ve birçok kaynaktan yoksun olarak devam eden bu süreç, birçok açıdan fiziksel, ekonomik, sosyal ve toplumsal risklere açıktır. $\mathrm{Bu}$ durumda bireyler, konumları ve koşulları itibariyle risklere ve tehditlere karşı savunmasız hale gelmekte ve çeşitli açılardan dezavantajlarla karşılaşmaktadır. "Savunmasız olma" ve "savunmasızlık" hali ise, her modern toplumun mikro, mezzo ve makro düzeylerde özel ilgi göstermesi ve tartışması gereken önemli durumlardır (Saha, 2019: 3). Savunmasız gruplara dâhil edilebilecek kişilere sosyal olarak dışlanmış, sınırlı kaynaklara sahip, kötü muamelelere maruz kalmış (psikolojik, fiziksel, cinsel, ekonomik vb.), önyargı ve ayrımcılığa uğramış kişiler örnek gösterilebilir. Bu kişiler tek ebeveynler, engelliler, yaşlılar, çocuklar, etnik azınlık gruplarına mensup kişiler, mental bozukluğu olan kişiler, evsizler, sığınmacılar ve mülteciler gibi olabilmektedir (Larkin, 2009, akt; Soner ve Avci, 2019: 15). Göçmenler de genellikle savunmasız nüfus grubu olarak tanımlanmakta ve psiko-sosyal ve fiziksel olarak risk altındaki gruplara dâhil edilmektedir (Derose ve ark., 2007: 1258). Savunmasızlığın sosyo-ekonomik kaynakların ve toplumsal destek sistemlerinin yoksun olmasıyla şekillendiği, siyasal ve sosyal marjinalleşme durumlarından önemli ölçüde etkilendiği bilinmektedir. Bireyler psiko-sosyal, ekonomik, duygusal ve temel insani ihtiyaçlarını çeşitli kaynaklardan ve destek sistemlerinden yoksun olduğunda gidermekte zorlanırlar. bu ihtiyaçların giderilmemesine bağlı olarak oluşan yeni sorunlarla karşılaşmaktadır. Göçmen grupların ihtiyaçlarının karşılanması, bulundukları ülke vatandaşlarına göre yasal, hukuki ve toplumsal açıdan daha farklı olabilmektedir. $\mathrm{Bu}$ farklılıklarla gelen güçlükler bireyleri savunmasız hale getirebilmektedir. Aile ya da grupların temel ihtiyaçlarının tespiti ve bu kapsamda oluşturulacak sosyal politikaların uygulanabilirliği, sistem açıklarından kaynaklanabilecek ya da ihmal ve istismar edilmeden doğabilecek mağduriyetlerin yaşanmasını önlemede savunmasızlık temel unsurlar olarak değerlendirilmektedir.

\footnotetext{
${ }^{2}$ https://data.unicef.org/topic/child-migration-and-displacement/migration/
} 
Savunmasız gruplarla ilgili önemli bir nokta ise savunmasızlı̆̆ın tanımlanmasının tam olarak yapılamaması ya da değerlendirmelerin eksik olmasıdır. Yapılacak olan yardımların, müdahalelerin ya da geliştirilecek olan sosyal politikaların bu çerçevede şekilleneceği bir gerçektir. Savunmasız grupların tanımlamasını genişletecek başka faktörlerin olduğunu söylemek mümkündür. Bunlardan biri, kişiye özgü olan veya doğuştan gelen kişisel durumlardır. $\mathrm{Bu}$ duruma anksiyete bozuklukları, Alzheimer, Otizm ve benlik saygisının düşüklüğü örnek gösterilebilir. Diğer bir savunmasızlık durumu da bireyden bağımsız çevresel faktörlerden kaynaklanan durumlardır (Yavuz, 2019). Bununla birlikte içinde yaşanan topluluk ya da gruba yönelik algı ve ön yargılar da savunmasızlıklara neden olabilmektedir. Evsiz olmak, bağımlılık, seks işçiliğii, savaş mağduriyeti, belirli gruplara yönelen dışlamacı politikalar bunlara örnek gösterilebilir (Brule ve Eckstein, 2017: 1873). Dışlama, damgalama, yabancı düşmanlığı ya da toplumsal uyumun sağlanamaması gibi durumlarda da savunmasızlıkların oluştuğu ve grupların marjinalize edilerek ötekileştirildiği ifade edilebilir.

Göç olgusunun ana temalarından biri olan ve savunmasızlık durumuna ilişkin bilinen önemli tablolardan biri de göçmenlerin maruz kaldığ 1 insan ticareti ve göçmen kaçakçılığıdır. Göç olgusuyla karakterize hale gelen insan ticareti ve göçmen kaçakçıllğı, göç literatüründe sıkça yer alan olgular olmakla birlikte (Karataş, 2020: 118); örseleyici ve travmatize edici yaşantılar olarak göçmenleri olumsuz etkilemektedir. İnsan ticareti ile mücadele, çağdaş insani yardım gündeminde üst sıralarda yerini korumaktadır (Akgün, 2016: 158). İnsan ticareti istatistiklerine bakıldığında 2020 y1lı itibarı ile küresel ölçekte 108.613 insan ticareti mağduru vakasının tespit edildiği görülmüştür (05.12.2020, MDP). Göçmenlerle yapılan bir araştırmada sosyal, politik ve ekonomik olarak savunmasız duruma düşen göçmenlerin, yaşama hakkı ve özgürlükleri bağlamında temel haklarından mahrum kaldığı ve haklarının ihlal edildiği tespit edilmiştir (Usman, 2014: 2857). Amerika Birleşik Devletleri'nde sınırda illegal göçmenleri yakalama vakaları ile ilgili yapılan bir araştırmada, 2017 yılında yapılan yakalamalarda bireylerin \%35'inin aileleri ile birlikte göç ettikleri, 2018 y1lında 168.000 ailenin sınırda yakalandığı tespit edilmiştir. Yine aynı tespite göre, bu geçişlerde en fazla savunmasız durumda olanların ise yaşlılar olduğu görülmüştür (2020 IOM, WMR).

Sosyal hizmet mesleği, bireylerin refah seviyesini yükseltmesine ve savunmasız grupların korunmasına adanmış bir meslektir (Farkas ve Romaniuk, 2020). Göçmenler de çoğu zaman farklı neden ve koşullardan kaynaklı olarak savunmasız ya da desteklenmeyen gruplar arasında yer alabilirler (Roestenburg, 2012). Bu bağlamda yürütülecek sosyal hizmet müdahalelerinde savunmasız grupların kimlerden oluştuğu ve bu gruplara ilişkin dinamiklerin anlaşılması önemli bir husustur. Bu araştırmanın kapsamını belirleyen, özellikle son on yıl içerisindeki iç çatışmalar, politik anlaşmazlıklar ve ülkelerin göç olgusuna ilişkin yasal düzenlemeler, göçmen sayısında artış ve göç süreçlerinin karmaşık bir hal alması neden olmuştur. Göç hareketliliklerinde önemli etkileri olan bu faktörler aynı zamanda savunmasızlık tablolarını içermekte ve bu durumu kolaylaştırmaktadır. Bu bağlamda Uluslararası Göç Örgütü (IOM) tarafindan son on yıl içerisinde küresel düzeyde hazırlanan altı rapor odak alınmış ve analiz edilmiştir.

Göç aşamasında veya göç ettikten sonra bireysel, ailesel, toplumsal ya da yapısal olarak meydana gelen durumlardan dolayı savunmasız duruma düşen göçmenlerin karşılaştıkları sorunların neler olduğunun anlaşılması ve uygun sosyal hizmet müdahalelerin neler olması gerektiği bu araştırmanın problemini oluşturmaktadır. Bu bağlamda, araştırmanın amacı, küresel olarak göç alanında faaliyet gösteren IOM, yayımladığı göç raporlarının içerik analizleri yapılarak savunmasız göçmen gruplarının yaşadığı sorun ve mağduriyetlerin değerlendirmesini yapmak ve bu durumu hazırlayan faktörlerin neler olduğuna ve 
süreğenliğine ilişkin durum tespiti yaparak savunmasız gruplarla ilgili sosyal politikalara ilişkin önerilerde bulunmak ve konu hakkında uygulayıcılara farkındalık kazandırmak olarak belirlenmiştir.

\section{IOM ve Savunmasız Gruplar}

IOM, insani ve düzenli göçlerin topluma ve göçmenlere fayda sağlayacağı ilkesinden hareketle, 1951 yılında hükümetler arası ve Birleşmiş Milletler sistemine entegre olarak kurulmuş uluslararası bir örgüttür. IOM küresel ölçekteki çalışmalarıyla, değişen göç dinamiklerine odaklanan, acil durumlarda harekete geçen ve özellikle savunmasız grupların dayanıklılıklarını geliştirmeyi misyon edinerek, göçmenleri güçlendirmenin yanı sıra göç hareketliliklerinin türleri ve etkileri noktasında da hükümetlerin kapasitesini arttırmayı hedefleyen bir örgüttür (27.12.2020, $\left.\mathrm{IOM}^{3}\right)$.

IOM, göç sorunları ve mağdur göçmenlerle ilgili sosyal sorumluluk projeleri ve saha çalışmaları yürütmektedir. Kriz sırasında göçmenlerin insani ihtiyaçlarını karşılamadaki rolünün yanı sıra, göçmen yardım programları, işgücü entegrasyonu, göç ve sınır yönetimi araştırmaları ve göç hareketleri ile ilgili veri toplama faaliyetlerinde de bulunmaktadır. Türkiye'nin de dâhil olduğu birçok ülkede göçün uzun vadeli etkilerini değerlendiren IOM, resmi kurum ve kuruluşlarla yakın iş birliği içindedir. Ayrıca IOM, 2020 yılında dünyayı etkileyen COVID-19 salgını çerçevesinde de çalışmalar yürütmüş ve bünyesinde "Bölgesel Tematik Çalışma Grupları” oluşturarak 28 ülkede müdahale planları geliştirmiştir. Durum raporları ve gelişmelere ilişkin güncel veriler kurumun resmî web sitesinde paylaşılmaktadır (05.12.2020, IOM).

Göç olgusuna ilişkin derinlemesine inceleme ve tespitlerle ilgili kamuoyunu bilgilendirmek amacıyla IOM tarafından 2000 yılından beri göç raporları düzenlenmekte ve paylaşılmaktadır. Son on yıl içerisinde 2010, 2011, 2013, 2015, 2018 ve 2020 yıllarında raporlar yayımlanmıştır. Raporlar incelendiğinde rapor odaklarının farklı olduğu, ancak 2018 ve 2020 Göç Raporlarının genel değerlendirmeler yapılarak hazırlandığı görülmektedir. Raporların yılları ve temaları şu şekildedir:

- 2010 Dünya Göç Raporu: Göçün Geleceği: Değişim İçin Kapasitelerin Güçlendirilmesi.

- 2011 Dünya Göç Raporu: Göç Hakkında Etkili İletişim Kurmak

- 2013 Dünya Göç Raporu: Göçmen Refahı ve Gelişimi

- 2015 Dünya Göç Raporu: Dünya Göç Raporu: Göçmenler ve Şehirler, Hareketliliği Yönetmek İçin Yeni Ortaklıklar

- 2018 Dünya Göç Raporu: Genel Rapor

- 2020 Dünya Göç Raporu: Genel Rapor

IOM tarafından 2019 yılında hazırlanan "Savunmasız Göçmenler Iç̧in Şiddet, İstismar ve Sömürüye Karşı Koruma ve Yardım Kılavuzu” nda savunmasız göçmenlerin etkilenebileceği faktörler ele alınmıştır. Kılavuzda yer alan modelde, savunmasız göçmenlerin, göç süresince ya da sonrasında şiddet, sömürü ve istismar nedeni ile yaşadıkları olumsuz deneyimlere odaklanılmıştır. $\mathrm{Bu}$ şekilde hassas duruma gelen göçmenlerin temel ihtiyaçlarının belirlenmesi, korunmalarının sağlanması ve gerekli destek mekanizmalarının harekete geçirilerek savunmasızlıklarının en aza indirgenmesi amaçlanmıştır. Bu modelde göçmenlerin parçası oldukları aile, grup ve topluluklar ve bulundukları sosyal çevre odak alınmıştır. Göçmenlerin, çeşitli düzeylerde, kendilerinden kaynaklı ya da bağımsız

${ }^{3}$ https://www.iom.int/mission 
durumlarla ilişkili savunmasızlıkları ele alınmıştır. $\mathrm{Bu}$ düzeyler bireysel, ailesel, toplumsal ve yapısal olmak üzere dört boyuttadır ve Şekil 1'de gösterilmiştir.

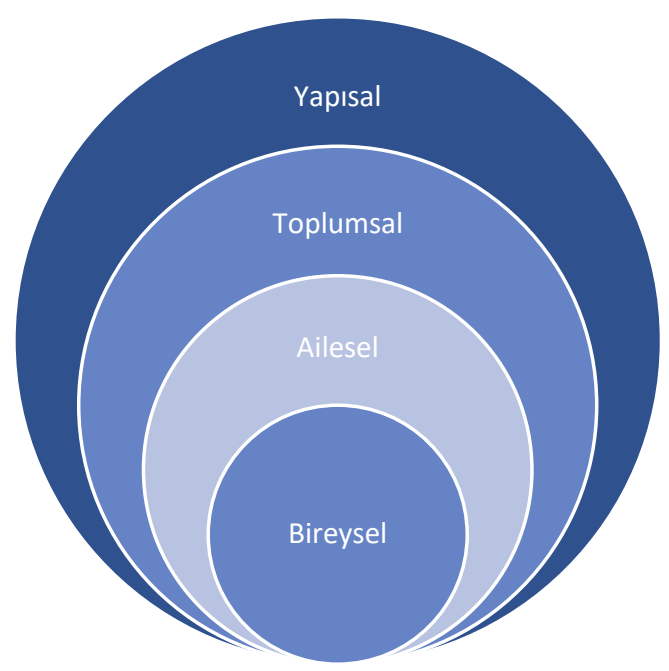

Şekil 1. Göçmenlerin Savunmasızlık Faktörleri Modeli (IOM, 2019) ${ }^{4}$

Bireysel faktörlerde toplumdaki statüler, fiziksel ve biyolojik özellikler, bireysel öyküler ve deneyimler, inançlar ve davranışlar, duygusal, psikolojik ve bilişsel karakterler gibi durumlar yer almaktadır. Ailesel faktörlerde ailenin büyüklüğ̈̈, bireyin aile içerisindeki rol ve konumu, ailenin geçmişi ve deneyimleri, sosyo-ekonomik durumu, ailede şiddet ve madde bağımlılık hikâyesinin olup olmadığı vb. sorunlar yer almaktadır. Toplumsal faktörlerde nitelikli eğitim firsatları, sağlık hizmetlerine ve sosyal hizmetlere erişim, geçim kaynakları yaratma firsatları, doğal çevre, sosyal normlar ve davranışlar yer almaktadır. Göçmenler toplumun ekonomik, kültürel ve sosyal yapılarından etkilenebileceği gibi bu yapılardaki rollerinden de etkilenebilirler. Güçlü sosyal sermaye ve kaynaklara erişim göçmenler için koruyucu ve destekleyici iken imkânların olmadığı topluluklar, göçmen bireyler ve aileleri için risk faktörü olabilmektedir. Yapısal faktörler ise bireylerin, ailelerin, toplulukların ve grupların bulunduğu genel çevreyi etkileyen ve göçmenlerin inançlarını şekillendiren ulusal, bölgesel ve uluslararası düzeyde tarihsel, sosyo-kültürel, ekonomik, politik, coğrafi koşulları ve kurumları içermektedir. Yapısal faktörler köklüdür ve kısa ve uzun vadede önemli etkiye sahiptir. Tüm faktörler ayrı başlıklarda ele alınsa da birbiri ile yakın ilişkili olduklarını ifade etmek önemlidir.

Sosyal hizmet uzmanlarının da aralarında bulunduğu saha görevlileri için 2018 yılında IOM tarafından hazırlanan "Savunmasızlıkları Azaltmak ve Göçmenleri Güçlendirmek" (Reducing Vulnerabilities and Empowering Migrants" ${ }^{5}$ ) isimli yayında, 'ihtiyaç sahibi göçmenler' ve 'savunmasız göçmenler' olarak iki ayrı tanımlama kriterleri oluşturulmuştur (IOM, 2018). Tanımlama kriterleri Türkçe’ye çevrilerek Tablo 1’de gösterilmiştir.

\footnotetext{
${ }^{4}$ https://publications.iom.int/books/iom-handbook-migrants-vulnerable-violence-exploitation-and-abuse

${ }^{5}$ https://reliefweb.int/report/world/reducing-vulnerabilities-and-empowering-migrants-determinants-migrant-vulnerability
} 
Tablo 1. İhtiyaç Sahibi Göçmenler ve Savunmasız Göçmenlerin Tanımlanması

\begin{tabular}{|c|c|c|}
\hline & İhtiyaç Sahibi Göçmenler & Savunmasız Göçmenler \\
\hline Kim & $\begin{array}{l}\text { Saha Görevlileri: } \\
\text { - Sinır geçiş noktalarındaki göç memurları } \\
\text { - Polis } \\
\text { - IOM ya da bölgede kayıtların } \\
\text { yapılmasında yardımcı olan sivil toplum } \\
\text { kuruluşlarının yetkilileri }\end{array}$ & $\begin{array}{l}\text { - Vaka Yöneticileri } \\
\text { - Vaka Çalışanları } \\
\text { - Sosyal Hizmet Uzmanları } \\
\text { - İdari Gözetim Altında Bulunan } \\
\text { Göçmenlere Uzmanlı Alanı } \\
\text { Kapsamında Yardım Edecek Göç } \\
\text { Memurları ya da Polisler. } \\
\text { - Bireysel, Toplumsal ya da Yapısal } \\
\text { Alanlarda gelen } \\
\text { savunmasızlıklar ile ilgili olarak } \\
\text { destek veren diğer ortaklar (toplum } \\
\text { liderleri ya da politika planlayıcıları). }\end{array}$ \\
\hline Ne zaman & $\begin{array}{l}\text { - Genelde göç hareketinin gerçekleştiği } \\
\text { dönemlerde, } \\
\text { - Bir göçmen yolculuğunda bir yerde } \\
\text { birkaç gün ya da saat duraklamaktadır. }\end{array}$ & 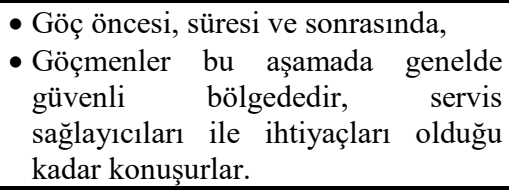 \\
\hline $\begin{array}{l}\text { Nasıl } \\
\text { (Metodolojiler ve } \\
\text { Araçlar) }\end{array}$ & $\begin{array}{l}\text { - Açıç̧a görülebilen savunmasızlık } \\
\text { durumlarının gözlemlenmesi (refakatsiz } \\
\text { çocuk ya da hamile kadın vb.) } \\
\text { - Kendini Tanımlama (Göçmenin, Göçmen } \\
\text { Yardım Merkezine kendisinin } \\
\text { başvurması ve yardım talep etmesi) } \\
\text { - Hızlı tarama formları } \\
\text { - Sinır görevlisinin zamanı ve yeteneği var } \\
\text { ise ikincil değerlendirmeleri yapması } \\
\text { - Diğer uygulama ortaklarını dikkate } \\
\text { alınması }\end{array}$ & $\begin{array}{l}\text { - İkincil değerlendirmelerin yapılması } \\
\text { - Savunmasızlı durumlarının } \\
\text { değerlendirilmesinin yapılması } \\
\text { - Müdahale planları } \\
\text { - Değerlendirme ve koruma } \\
\text { prosedürleri } \\
\text { - Diğer kurum ve kuruluşlar tarafından } \\
\text { geliştirilen savunmasılılı } \\
\text { değerlendirmeleri (sosyal güvence } \\
\text { kapsamı, yoksulluk durumları, sağlık } \\
\text { hizmetlerine erişim vb.) }\end{array}$ \\
\hline Neden & $\begin{array}{l}\text { - Bireysel bazda acil ihtiyaçların } \\
\text { karşılanması (su, yemek, kısa süreli } \\
\text { barıma, acil sağlık hizmeti) } \\
\text { - Göçmenlerin ihtiyaca göre diğer hizmet } \\
\text { kuruluşlarına havalesi, } \\
\text { - Genel veri toplama işlemlerinin yapılması }\end{array}$ & $\begin{array}{l}\text { - Bireysel bazda ihtiyaç duyuluyorsa } \\
\text { acil yardım hizmetlerinin sağlanması, } \\
\text { - Göç aşamalarında ailesel, toplumsal } \\
\text { ya da yapısal savunmasızlıklar var } \\
\text { ise bunların belirlenmesi, } \\
\text { - Bireysel düzeyde daha kapsamlı } \\
\text { müdahale çeşitlerinin oluşturulması } \\
\text { (danışmanlık, geçim, eğitim, uzun } \\
\text { süreli barınma düzenlemeleri) } \\
\text { - Aile, toplum ve yapisal düzeylerde } \\
\text { müdahalelerin geliștirilmesi. }\end{array}$ \\
\hline
\end{tabular}

Tablo1'den anlaşılacağı gibi, ihtiyaç sahibi göçmenlerle ilgili müdahaleler ve savunmasız göçmenlere yönelik müdahale plan ve araçları birbirinden farklılaşmaktadır. Sosyal hizmet uzmanlarının savunmasız göçmenlerin göç süreçlerine ilişkin deneyimlerine odaklandıkları, durumlarını değerlendirerek müdahale planları hazırladıkları, koruma prosedürlerini takip ettikleri ve ilgili kurum ve kuruluşlarla destek mekanizmalarını harekete geçirmek için koordinasyon içerisinde oldukları görülmektedir. 


\section{Yöntem}

Araştırma, amacına uygun olarak nitel yöntemlerle gerçekleştirilmiş olup araştırma deseni doküman analizidir. Doküman analizi, yazılı belge içeriklerinin ele alındığı ve sistematik analize tabi tutulduğu bir nitel araştırma yöntemidir. Doküman analizi, basılı ve elektronik materyaller olmak üzere tüm belgeleri incelemek ve değerlendirmek için kullanılan sistemli bir yöntemdir (Kıral, 2020: 173; Özkan, 2020) Bir araştırma yöntemi olarak doküman analizi, nitel çalışmalarda özellikle fenomenin, olayın, organizasyonun veya programın zengin tanımlarını üreten yoğun çalışmalarda kullanılabilmektedir (Bowen, 2009: 32). Özellikle göç alanında hizmet veren resmi kuruluşlarda görevli sosyal hizmet çalışanlarının bilgi ve beceri temelinin güçlendirilmesi oldukça önemli bir konudur. IOM raporlarının analiz edilmesinin göç alanında çalışan sosyal hizmet görevlilerinin savunmasızlık durumlarını daha iyi anlamaları bakımından katkı sağlayacağ düşünülmektedir. Bu kapsamda IOM tarafından hazırlanan son on yılda çıkarılmış olan göç raporları analiz edilmiştir.

\subsection{Veri Toplama ve Analiz Süreci}

Araştırma kapsamında veri analizi geçekleştirmek üzere IOM tarafından yayınlanan $2010^{6}$ (295 Sayfa), $2011^{7}$ (184 Sayfa), $2013^{8}$ (220 Sayfa), $2015^{9}$ (227 Sayfa), 2018 ${ }^{10}$ (364 Sayfa) ve $2020^{11}$ (498 Sayfa)yılı göç raporlarının İngilizce versiyonları incelenmiştir. Raporların İngilizce versiyonları, araştırmacılar haricinde alanında uzman iki farklı kişi tarafından da okunmuş ve Türkçe'ye çevrilmiştir. Raporlarda yapılan taramalarda özellikle savunmasız gruplar ile ilgili durumlar tespit edilerek ilgili bölümlerin içerik analizleri yapılmaya çalışılmıştır. Yapılan taramalarda yıllar ana kod olma özelliği taşımış, sonrasında ise raporlarda tespit edilen savunmasızlık faktörleri alt kod olarak kodlanmıştır. Savunmasızlık yaratan faktörlerin geçen süre zarfinda mevcudiyetini sürdürüp sürdürmediğinin tespit edilmeye çalışılması ise yıl bazlı kodlama yapılmasının bir diğer nedenidir.

IOM raporlarını kodlamak üzere MAXQDA 2020 nitel veri analiz programı kullanılmıştır. Yazılım kullanımı öncesi raporlarda hangi kıstaslara göre (savunmasızlık durumu tespit edilen grupların yer aldığı bölümlerin tespit edilmesi) inceleme yapılacağı ile ilgili planlama yapılmıştır. Taramalarda savunmasızlık durumları tespit edilerek sistematik kodlamalar yapılmıştır. Birey, aile, kadın ve çocuk bazında oluşabilecek savunmasızlıklar bireysel, ailesel ve toplumsal boyutlarda ele alınmış ve kodlamaları yapılmıştır. Bu kapsamda kodlamalar iki safhalı olarak gerçekleştirilmiştir. İngilizce raporda yapılan taramalarda ilgili birimler tespit edilerek Türkçe'ye çevrilmiş, daha sonra kodlanmak üzere metin belgelerine aktarılmıştır. Savunmasız gruplar ile ilgili olarak toplamda 415 kodlama yapılmıştır. Yapılan kodlamalarda Savunmasız- Hassas Gruplar, Aile, Kadın ve Çocuk temaları oluşturulmuş, sonrasında rapor yılları kategori olarak belirlenmiştir.

\section{Bulgular}

$\mathrm{Bu}$ bölümde araştırma bulgularına, raporlarda yer alan temalara ve kodlara ilişkin açıklamalara yer verilmiştir. Savunmasız gruplar ile ilgili genel kodlamaların sayısı 197 olup

\footnotetext{
${ }^{6}$ https://www.iom.int/world-migration-report-2010

7 https://www.iom.int/world-migration-report-2011

8 https://www.iom.int/wmr2013

9 https://www.iom.int/world-migration-report-2015

${ }_{10} \mathrm{https} / / /$ publications.iom.int/books/world-migration-report-2018

${ }^{11}$ https://publications.iom.int/books/world-migration-report-2020
} 
çocuklar 104, kadınlar 70 ve aileler ile ilgili 44 olmak üzere toplamda 415 kodlama yapılmış ve tema dağglımı Tablo 2'de gösterilmiştir.

Tablo 2. Yapılan Kodlamaların Temalara Göre Dağılımı

\begin{tabular}{lcc}
\hline \multicolumn{1}{c}{ Tema } & $\boldsymbol{n}$ & \% \\
\hline Savunmasız- Hassas Gruplar & 197 & 47,47 \\
Çocuk & 104 & 25,06 \\
Kadın & 70 & 16,87 \\
Aile & 44 & 10,60 \\
\hline Toplam & $\mathbf{4 1 5}$ & $\mathbf{1 0 0 , 0 0}$ \\
\hline
\end{tabular}

Temaların altında bulunan yıl bazlı alt kodlamalar, Şekil 1'de gösterilen ve IOM tarafindan belirlenmiş "Göçmenlerin Savunmasızlık Faktörleri Modeli" kapsamındaki dört kategori bağlamında kodlanmıştır. Bu kodlamalar: Bireysel, Ailesel, Toplumsal ve Yapısal Faktörlerdir. Belirtilen kod-alt kod sistemi Tablo 3’te verilmiştir.

Tablo 3. Kod - Alt Kod Hiyerarşisi

\begin{tabular}{|c|c|c|c|}
\hline Tema & $\begin{array}{c}\text { Alt } \\
\text { Kodlar }\end{array}$ & Kategoriler & $\begin{array}{c}\text { Sorunsalı Yıllara Göre Devam Eden } \\
\text { Alt kategoriler }\end{array}$ \\
\hline $\begin{array}{c}\text { Savunmasız- Hassas Gruplar } \\
\text { Çocuk } \\
\text { Kadın } \\
\text { Aile }\end{array}$ & 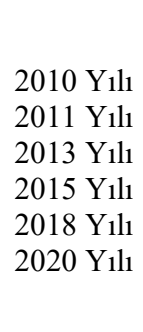 & $\begin{array}{l}\text { Bireysel } \\
\text { Faktörler } \\
\text { Ailesel } \\
\text { Faktörler } \\
\text { Toplumsal } \\
\text { Faktörler } \\
\text { Yapisal } \\
\text { Faktörler }\end{array}$ & $\begin{array}{l}\text { Statü Belirsizliği } \\
\text { İnsan Ticareti } \\
\text { İnsan Kaçakçllığı } \\
\text { Koruma Sistemlerinin Yetersizliği } \\
\text { Yasal Düzenlemelerin Eksikliği } \\
\text { Uyum Politikalarının Yetersizliği } \\
\text { Temel Hak ve Hizmetlere Erişim } \\
\text { İdari Gözetim } \\
\text { İstismar ve Sömürü }\end{array}$ \\
\hline
\end{tabular}

\subsection{Savunmasız-Hassas Gruplar}

Taramalar sonrası analizlerde en fazla kodlanan tema Savunmasız-Hassas Gruplar olmuş ve bu temaya ilişkin 197 kodlama yapılmıştır. Yapılan incelemede savunmasız grupların raporlarda çocuk, kadın, engelli, yaşlı ve özel gereksinimi olan bireylerden oluştuğu anlaşılmıştır. Bu başlıkta savunmasız göçmen gruplarıyla ilgili bireysel, ailesel, toplumsal ve yapısal faktörler ele alınmıştır.

\subsubsection{Bireysel Faktörler}

İstihdam alanında karşılașılan sorunlar: Savunmasız hassas grupların durumlarına ilişkin bireysel faktörlere bakıldığında, istihdam alanında karşılaşılan sorunların tüm raporlarda dağılım gösterdiği ve ekonomik problemlerin göçmenler için ciddiyetini koruyan bir sorun olduğu görülmektedir. Raporlara göre göçmenlerin düzensiz iş kollarında, yarı zamanlı ve sürdürülebilirlikten uzak çalıştığı görülmekte ve bu nedenle ekonomik istikrarsızlıklar yaşadıkları belirtilmektedir. Ayrıca yapılan kodlamalardan elde edilen veriler ışığında 
göçmenlerin kalifiye olmayan ve eğitim düzeyleri düşük bireyler olmaları nedeniyle de işsizlikle karşı karşıya oldukları görülmektedir. Ülkelerin ekonomik gerileme dönemlerinde, geçici iş kollarında (inşaat, imalat ve hizmet vb.) çalışan göçmenlerin bu durumdan etkilendikleri ve işsiz kalarak sosyo-ekonomik olarak savunmasız duruma düştükleri anlaşılmaktadır. Raporlarda belirtilen bir faktör ise göçmenlerin çalışma hayatında sömürülmesi durumudur. Daha evvel belirtildiği üzere, farklı düzeylerdeki faktörler birbiri ile ilişkili olmaktadır. Yapısal faktörlerden statü belirsizliğinin iş hayatında sömürülme ve istismar edilme riskini arttırması da bu durumun örneklerindendir. Yapılan analizlerde özellikle iş hayatında yapılan sömürünün en önemli nedeninin göçmenlerin statülerinin belirsizliğinden kaynaklandığı anlaşılmıştır. İstihdam alanında özellikle kadın göçmen işçilerin "aşırı derecede savunmasız konumlarda" olduğu ve söz konusu durumun yıllar içinde farklılık göstermeden süreğenliğini koruduğu görülmüştür. Göçmenler arasında özellikle iş kayıplarının olması ve işsizliğin yaygınlaşması savunmasızlık durumlarının artmasına neden olan faktör olarak raporlarda yer almıştır.

Ülkelerde yasadıșı kalıșlar ve ilișkili riskler: Ülkelerde yasadışı şekilde kalmak ve bununla birlikte gelişen riskler göçmenleri savunmasız bırakabilmektedir. Düzensiz göçmenler gidecekleri yere güvenli bir şekilde ulaşsalar bile yetkililerden kaçmaya ve yasa dışı olarak çalışırken genellikle kendilerini çok savunmasız durumlarda bulabilmektedirler. Göçmenlerin kanuni hakları olsa da bazı durumlardan kaynaklı yakalanma ve sınırdışı edilme riskleri bulunmaktadır.

Temel insan ihtiyaçlarının eksikliği:_Göçmenlerle ilgili bir diğer önemli savunmasızlık unsurudur. Göç raporlarında, barınma, temiz içme suyu, psiko-sosyal destek, sağlık hizmetleri ve beslenme gibi giderilmemiş gereksinimlerin, göçmenler için savunmasızlık durumu yaratan temel insan ihtiyaçları arasında olduğu görülmektedir. Ayrıca göçmenlerin temel insan ihtiyaçlarına erişimi için kaynakların ilk aşamada göç edilen ülkeler tarafından sağlanamadığı anlaşılmaktadır.

Güvenlik sorunları: Göçmenlerin göç yolcuğunda ya da göç sonrası hedef ülkede güvenlik sorunları yaşadığ ve kendilerini emniyete alamadıkları için mağdur duruma düştükleri anlaşılmaktadır. Yapılan analizlerde göçmenlerin kendilerini güvende hissetmelerine ilişkin oranların düşük olduğu göç raporlarına yansımıştır. Ayrıca göçmenlerin daha önce saldırıya uğramalarından ya da mülklerini kaybetmelerinden dolayı güven konusunda travmalarının olduğu anlaşılmaktadır. Güvenlik kapsamında bir diğer ele alınan husus ise, göçmenlerin gittikleri ülkedeki ucuz yerleşim birimlerinde ya da metruk binalarda ikamet etmelerinden kaynaklı yaşadıkları problemlerdir. Bu tür yerleşim yerleri genellikle suç unsurunu barındıran yerler olabilmekle birlikte, göçmenlerin suç çetelerince kullanılmasını, istismar edilmelerini ya da saldırılara karşı savunmasız kalabilmelerini kolaylaştırmaktadır.

Göc koşullarl ve itici faktörler: Raporlarda yer alan önemli bir diğer konu ise göçün gerçekleşme koşullarının ve göçe iten faktörlerin göçmenleri savunmasız kılmasıdır. $\mathrm{Bu}$ faktörler göçmenlerin göç sonrası refahında önemli rol oynayabilmektedir. Yapılan analizlerde ağır koşullarda göç edenler, yaşadıkları travmatik deneyimlerin etkilerini göç sonrasında hissetmekle birlikte sığınmacılar, mahsur kalmış göçmenler, insan ticaretine maruz kalanlar, çatışmadan ve insani krizlerden kaçanlar göç yolunda savunmasız kalabilmektedir.

Psiko-sosyal savunmasızlıklar: Analizlerde travmatik deneyimlerle ilişkili psiko-sosyal savunmasızlıkların oluşabildiği ve savaş, çatışma, güvensizlik veya doğal afet sonucu ortaya 
çıkan zorla yerinden edilmelerin genellikle göçmenlerin psiko-sosyal sağlı̆̆ ve refahı için tehdit oluşturabildiği tespit edilmiştir. Bunun yanında, gönüllü, iyi planlanmış göçlerde bile, aileden ve arkadaşlardan ayrılma, transit ve hedef ülkelerde sömürü, ayrımcılık, yabancı düşmanlığı, hastalıklar ve cinsiyete dayalı şiddet gibi olguların göçmenlerin psikolojik risklere karşı savunmasızlıklarını artırabildiği anlaşılmaktadır. Özellikle 2020 Göç Raporu'nda göçmenlerin sağlık koşullarının, göç aşamalarındaki (menşe, transit ve hedef ülke) yolculuk koşullarına göre değişebildiği yer almaktadır. Savunmasız durumlarda göçmenlerin korunması, geleneksel savunmasızlık kategorilerinin (kadınlar, çocuklar ve insan ticareti mağdurları vb.) ötesine geçebilmektedir. Göçmenlerin seyahat ettikleri koşullar veya menşe, transit ve hedef ülkelerinde karşılaştıkları zorluklar yeni savunmasızlık kategorileri oluşturabilmektedir.

Insan hakları ihlalleri ve sömürüler: Raporlarda görülen bir diğer önemli nokta ise sistematik olarak bireysel düzeyde maruz kalınan hak ihlalleri ve sömürülerdir. Özellikle kadın göçmenlerin seks işçisi olarak sömürüldükleri görülmektedir. Göçmenlerin seyahat ettiği, yaşadığı veya çalıştığı koşullar onları özellikle bulaşıcı ve bulaşıcı olmayan hastalıkların yanı sıra kazalara, şiddete ve istismara karşı savunmasız hale getirebilmektedir. Ayrıca travma yaşayan göçmenlerin sığındıkları yerlerde taciz ve aşağılanmaya karşı savunmasız kaldıkları tespit edilmiştir.

\subsubsection{Toplumsal Faktörler}

Uyum: Göçmenlerin toplumsal faktörlerden kaynaklanan savunmasızlıkları göç raporlarına yansımıştır. Göçmenlerin toplumsal düzeyde uyum konusunda savunmasızlıklar yaşadıkları görülebilmektedir. İş piyasasına uyum ile ilgili olarak da göçmenlerin hak kayıpları yaşadığ tespit edilmiştir. Gerek çalışma hayatı gerekse de toplumsal düzeyde yaşanan dil sorunu uyum problemlerini beraberinde getirebilmektedir. Bazı alanlarda göçmenlerin çalışması ya da görev almasının yeni gelen göçmenler ve temel hizmetler arasında köprü görevi gördüğü değerlendirilse de göçmenlerin uyumu konusunda daha somut adımların atılması gerekliliği vurgulanmıştır.

Toplumsal katılım: Göçmenlerin toplumsal katılımlarıyla ilgili problemler onları savunmasız kılan bir diğer faktördür. Yapılan analizlerde toplumun göçmenlerin toplumsal katılımında ana aktör olması gerekirken, ev sahibi toplumun göçmenlerin katılımı konusunda pasif durumda oldukları ve genel olarak göçmenlerle ilgili olumsuz tartışma durumlarında konuya dahil oldukları anlaşılmaktadır. Buradan hareketle ev sahibi toplumun, toplumsal katılımı engelleyen hareketlerinin göçmen gruplarının ötekileştirilmesine neden olduğu/olabileceği değerlendirilmektedir. Yapılan analizlerde kamuoyu tutumunda tepkiselliklerin oluşması, yabancılara tolerans seviyelerinde düşüş olması, ayrımcılık ve yabancı düşmanlığının kendini hissettirmesi gibi hususların göçmen gruplarının toplumsal katılımını engelleyici faktörler olduğu anlaşılmıştır.

Kentleşme: Toplumsal faktörlerle ilgili olarak raporlarda sıkça kodlanan bir diğer konu ise kentleşmenin göçmenler üzerindeki etkisidir. Özellikle kentleşme sürecinde bulunulan ülke toplumu ve göçmenler arasında bazı farklılıkların ve eşitsizliklerin olduğu görülebilmektedir. Sağlık, barınma, eğitim vb. temel ihtiyaçlara ulaşmada aksaklıklar yaşanması ve temel gıda kaynaklarındaki fiyat artışı göçmenlerin toplumsal refahlarını uzun vadede etkileyebilmektedir. Kentsel topluluklar içindeki en zayıf, en savunmasız sosyal gruplar arasında göçmenler gösterilmektedir. Bu nedenle özellikle göçmenlerin marjinalleştirilmesi ile birlikte toplumsal çözümlerin sağlanamayacağı analizlerde görülebilmektedir. Sosyoekonomik düzeyi düşük yerlerde yaşamanın ve marjinalleşmenin göçmenlerin kayıt dış1 işlerde çalışarak hayatlarını sürdürmesini etkilediği görülmektedir. 
Ülke krizleri: Raporlarda göçmenlerin yaşamlarını sürdürdükleri ülkelerin deneyimledikleri siyasi ya da ekonomik kriz dönemleri öncesi ile sonrasına ilişkin analizlerde yer almaktadır. Krizlerin küresel çapta etkilerinin olduğu söylenebilir. Yaşanan krizlerle birlikte ülke vatandaşlarının olumsuz etkilendiği ve hayat koşullarının insani ihtiyaçları karşılamada yetersiz kaldığı görülebilmektedir. Yasal, ekonomik ve sosyal statüleriyle ilişkili savunmasızlıkları olan göçmenlerin zorluklarla başa çıkma yeteneklerinde azalma görülmektedir.

\subsubsection{Yaptsal Faktörler}

Statü belirsizliği: Yapısal faktörlerin odağında daha çok yasal düzenlemeler, küresel sorunlar ya da sosyal politikalar yer almaktadır. Statü belirsizliği göçmenlerin savunmasız konumda kaldığı en önemli durumlardan biridir. Göç raporlarında yapılan analizlerde özellikle statü belirsizliğinin ya da statülere göre temel hak ve hizmetlere erişimdeki alt yapı eksikliklerinin mağduriyetler yarattığı tespit edilmiştir. Özellikle düzensiz statüye sahip göçmenlerin iş hayatında sömürüye açık olduğu görülmektedir. Düzenli ikamet statüsüne sahip olmayan kadın, çocuk ve yaşlılar gibi özel sağlık ihtiyaçları olan grupların temel sağlık hizmetlerine erişimde problemler yaşadığı anlaşılmıştır. Özellikle düzensiz göçmenlerin statü belirsizliğinin olması, iş piyasasında sömürü aracı olarak kullanılırken kayıt işlemlerini yerine getirmemek ya da statüye sahip olmamak temel hak ve hizmetlere erişimde sinırlayıcı etkiye neden olabilmektedir. Y1llara göre yapılan analizde statü belirsizliği problemi ile ilgili çözüm yollarının geliştirilmesinde yol kat edilemediği ve sorunun mevcudiyetini koruduğu görülmektedir.

Sosyal güvence: Sosyal güvenceden yoksunluk göçmenler için bir diğer yapısal savunmasızlık faktörüdür. Raporlarda elde edilen verilere göre özellikle ekonomik kriz yaşayan ülkelerde göçmenlerin sosyal güvence eksikliğinin savunmasızlıklara neden olduğu değerlendirilmiştir. Ülke vatandaşlarına göre iş hayatına katılımda yasal zorluklar yaşayan göçmenlerin, bu zorluklardan dolayı kayıtsız çalışarak sosyal güvenceden mahrum bırakıldıkları görülmektedir. Bununla birlikte sosyal güvence kapsamına alınma ile ilgili yasal düzenlemelerin ülkelere göre farkl1l1k göstermesi ya da yasal düzenlemelerin yapılmaması da sosyal güvence savunmasızlığının bir diğer önemli boyutudur.

Temel hak ve hizmetlere erişim: Göç raporlarında elde edilen bir diğer savunmasızlık da temel hak ve hizmetlere erişimde yaşanan sorunlardır. 2010 yılında yayımlanan Göç Raporunda bu duruma yönelik tespit şu şekildedir:
"Çoğu zaman düzensiz göçmenler, gerçekten hak sahibi olabilecekleri temel hizmetlere bile erişemiyor veya bu konuda isteksizler ve yardımın yükü dini gruplara (camii, kilise vb.) ve sivil toplum kuruluşlarına düşüyor."

Düzensiz göçmenlerin asgari acil hizmetler dışında diğer hizmetlere ulaşmada zorluklar yaşadıkları yapılan analizlerde tespit edilen bir durumdur. Yıllara göre yapılan analizde göçmenlerin özellikle sağlık hizmetlerine erişimde problemler yaşadığ 1 ve bu durumun hala mevcudiyetini koruduğu tespit edilmiştir. Göçmenlerin genellikle kamu sağl1k hizmetlerinin dışında bırakıldıkları, özel sağlık ihtiyacı olan kadın, çocuk ve yaşlıların yer aldığı dezavantajlı savunmasız grupların mağduriyetler yaşadığı anlaşılmaktadır. Bir diğer vurgulanmak istenen durumda 2020 yılında, COVID-19 salgını öncesi yayınlanan Göç Raporundaki ifadedir:

"Mülteciler, sığınmacılar ve düzensiz göçmenlerin dahil olduğu bazı göçmen grupları, bulaşıcı hastalıklara karşı özellikle savunmasız 
olabilir ve ev sahibi nüfustan daha kötü sağllk sorunlarl yaşayabilir veya belirli bulaşıcı hastallkların yüksek oranda görüldüğü yerlerden gelebilirler. Bu gruplar hedefli taramalardan geçmeli ve sağllk müdahalelerinden yararlanmalıdırlar."

Sağllk hizmetlerine erişim: Hizmetlere erişimde problem yaşayan göçmenlerin bulaşıcı hastalıklara karşı daha fazla savunmasızlığı bulunmaktadır. COVID-19 salgını ile birlikte hastanelerin doluluk oranlarının artması nedeniyle göçmenlerin, sağlık kuruluşlarına erişimde problemler yaşayabileceği değerlendirilmektedir. Raporlarda hassas durumda bulunan düzensiz göçmenlerin sağlık sorunlarına ilişkin yapılan kodlamalarda elde edilen sonuçlarda göçmenlerin sağlık hizmetlerine sınırlı erişimlerinin olduğu ya da hiç erişimlerinin olmadığ 1 , önleyici ve temel sağlık hizmetlerinden yararlanmak için ödeme güçlüklerinin yaşandığı, güvenli ya da yasal çalışma şartlarının kısıtlı olduğu ya da hiç olmadığı, sınır dışı edilme korkusunun neden olduğu sağlık hizmetlerini almada gönülsüz oldukları ve buna bağlı ruh sağlığı sorunlarının var olduğu bilgilerine ulaşılmıştır.

LGBTIQ+ göçmenler: Raporlarda savunmasız durumlarda yer alan gruplardan biri LGBTIQ+ göçmenlerdir. Rapor analizlerinde ayrımcılık, şiddet ve kötü muamele mağduru LGBTIQ+ göçmenlerin yapmış oldukları sığınma taleplerinde cinsiyet ve cinsel kimliği ispatlamaya yönelik stres, travmatik stres bozukluğu, intihar eğilimi, madde bağımlılı̆̆ı, insan kaçakçılarının istismarına uğrama, kötü çalışma koşulları ve özgürlüklerinin kısıtlanması gibi sorunlar yaşadığı tespit edilmiştir.

Doğal afetler ve iklim değissikliği: Yapılan taramalarda doğal olayların neden olduğu yerinden edilmeler kapsamında da savunmasız duruma gelen göçmenlerin olduğu tespit edilmiştir. Özellikle yavaş gelişen ya da hızlı başlayan afetlere karşı savunmasızlıkların olduğu görülmektedir. Deniz seviyesindeki yükselme, kuraklık, sel baskınları vb. durumlar, insanları, özellikle çocukları, engellileri ve yaşlıları savunmasız durumda bırakabilmektedir.

Sosyal politika önerileri: Savunması-hassas gruplar için sosyal politika önerileri, raporlarda araştırmacılar tarafından kodlaması yapılan bir diğer kategoridir. Raporlarda bu bağlamda ilk ele alınan durumlardan biri topluluk haritalandırmasının yapılmasıdır. Yapılan analizlerde topluluk haritalandırmasının, kitlenin demografisini tanımlamada, mevcut sosyal kaynakları belirlemede ve yardıma ihtiyaç duyan savunmasız haneleri bulmada etkin bir rol oynayacağ belirtilmiştir. Sağlık hizmeti sağlayıcıları ve göçmen topluluklarının işbirliği ile söz konusu haritalandırmanın yapılabileceği görülmektedir. Ayrıca taramalarda afet riskini azaltma mevzuatı ve planlamasında, toplumsal cinsiyet konularının ve hassas grupların ihtiyaçlarının dikkate alınarak düzenlenmesi, iklim değişikliğinin sık olduğu bölgelerde acil eylem planlarının hazır tutulması gerektiğine ilişkin önerilerin yer aldığı anlaşılmıştır. Çocuklar, engelliler ve yaşlılar dahil tüm hassas grupların temel ihtiyaçlarına özel önem verilerek cinsiyet engellerinin ve ayrımcılığının özel olarak ele alınması, yardımların planlanması aşamasında farklı kurum ve kuruluşların sorumluluklarının açıç̧a belirlenmesi, toplumsal programlar kapsamında temel hak ve hizmetlere erişimlerin sağlanması, sağlık, psiko-sosyal destek ve toplumsal istikrar çabalarının sosyal politika planlamalarında yer alması gerektiği belirtilmiştir.

Göçmen hakları: Göçmenlerin hakları açısından koşulsuz saygı, aile birliği, eşit muamele, kazanılmış haklar, savunmasız durumdaki çocuk göçmenler veya yabancılar için daha fazla koruma, göç politikalarının geliştirilmesine yönelik uzmanlık alanlarının geliştirilmesi ve kırılgan grupların, kadınların, çocukların, yaşlıların ve düzensiz statüdeki göçmenlerin sosyal ve maddi ihtiyaçlarının ele alınması ve eşit haklarla firsat eşitliğinin sağlanması gibi alanlar göç raporlarında geniş yer tutmuştur. Kadın göçmenlerin karşılaştığı belirli yapısal engelleri 
ve eşitsizlikleri ortadan kaldıran politikaların benimsenmesi, yalnızca ekonomi alanında değil, diğer politika alanlarında da kadın göçmen odaklı çalışmaların yapılması, ayrıca kadın göçmenlerin şiddet, istismar ve sömürü riskiyle karşı karşıya bırakabilecek savunmasız durumlardan korunması için gerekli tedbirlerin alınması yapılan analizlerde tespit edilmiştir.

Sivil toplum kuruluşları: IOM, sivil toplum kuruluşu olarak göçmenlere birçok konuda destek mekanizmaları sunmaktadır. IOM göç raporlarında sivil toplum kuruluşlarına ilişkin etkili rol ve sorumluluklara da yer verilmiştir. Bu kapsamda sivil toplum kuruluşlarının özellikle marjinal göçmen grupları arasında entegrasyonu desteklemede önemli bir rolü olduğu anlaşılmıştır. Bununla birlikte kriz operasyonlarında hükümetlere teknik destek ve göç sonrası göçmen topluluklarına yardım ve destek hizmetleri sağlanmaktadır. Yapılan analizlerde, kriz öncesinde, sırasında ve sonrasında göçmen profillerinin çeşitliliğini tanımlamak ve göçmenlerin krizlerle başa çıkmaları için gerekli destek mekanizmalarını çalıştırmak noktasında sivil toplum kuruluşlarının faaliyetlerinin olduğu görülmektedir.

Insan ticareti: Önemli yapısal faktörlerden biri olan insan ticareti, kodlamalarda en fazla kod sayısına sahip kategori olarak belirlenmiştir. 2020 Göç Raporuna göre, cinsel sömürüyü hedef alan insan ticareti, Avrupa'da insan ticaretinin baskın biçimi olmaya devam etmektedir (\%56). Bunu işgücü sömürüsü (\%26) ve zorla dilenme ve organ mafyası (\%18) gibi diğer sömürü biçimleri izlemektedir. Kadınlar, savunmasız gruplar içinde en çok bu mağduriyete uğrayanlardır (mağdurların \%68'i). Kadınların genellikle bakım ve ev işlerinde veya zorla fuhuş yaptırılarak sömürüldükleri görülmektedir. İnsan ticareti, göç raporlarında göçmenlerin insan haklarını ihlal eden, devletlerin egemenliğine zarar veren ve özellikle sömürüye dayalı bir olgu olarak gösterilmektedir. Ayrıca insan ticareti ile ilgili koruma mekanizmalarının işlememesi göçmenleri insan tacirlerine karşı savunmasız bırakmaktadır.

\subsection{Göçmen Aileler}

Göçmen ailelere ilişkin savunmasızlıklar bu tema altında kodlanmış olup söz konusu savunmasızlıklar, ailesel faktörler ve yapısal faktörler kategorileri altında incelenmiştir. Aile ile ilgili savunmasızlıkların kodlama sayısı 44'tür.

\subsubsection{Göçmen Ailelerle İlgili Ailesel Faktörler}

Aile refah düzeyi: Göç raporlarında yapılan kodlamalarda göçmen ailelerin refah düzeylerinin düşüşü ile beraber savunmasızlıkların oluştuğu görülmektedir. Ailelerin yoğun stres altında kalmasının başlıca nedeninin sosyo-ekonomik zorluklar olduğu, stres yoğunluğunun artması ile birlikte aile bireylerinin genel sağlı durumlarında olumsuzlukların yaşandığı anlaşılmaktadır.

Geride kalma durumu: Aile faktörleri ile ilgili bir diğer kategori de göçmenlerin geride bıraktıkları aileleridir. 2013 Göç Raporu'nda göçmenler ile yapılan görüşmelere yer verilmiş ve bu röportajlarda göçmenler geride bıraktıkları aileleri ile ilgili endişe duyduklarını ancak aile üyelerine daha iyi bir gelecek sunma kaygısı ve amacı ile göç hareketini gerçekleştirdiklerini dile getirmişlerdir. Geride bırakılan aileler ile ilgili raporlarda yer alan savunmasızlıklardan birisi de duygusal zorluklardır. Geride birakılan aileye para transferinde sıkıntıların olması ya da daha sık para gönderememe durumu göçmenlerde strese yol açmıştır. Bununla birlikte ailelerine daha fazla para göndermek için kendi yaşam kalitelerini düşüren göçmenlerin ekonomik sorunlar yaşadığı görülmektedir. Yapılan analizlerde ayrıca göç eden kişinin ailelerine daha iyi sağlık ve eğitim hizmetleri sağlama düşüncesinde olduğu, ancak aile olarak menşe ülkede de temel hak ve hizmetlere ulaşmada sıkıntılar yaşadığı görülmektedir. 
Göc kararları: Raporlara ilişkin analizlerde, aile bireylerinin rollerinin göç kararlarını doğrudan etkileyebildiği görülmektedir. Gençlerin göç kararları, çocuk göçmenlerin kararlarına göre daha bağımsız yapıda olabilmektedir. İhtiyaç sahibi ya da bakıma muhtaç çocukları olan ve göç kararı alan ebeveynler çocuklarını geride bırakma ya da kendileri ile birlikte götürme konusunda kararsız kalabilmektedirler. Yapılan kodlamalarda çocukların geride bırakılması ile ilgili nedenlerin başında ailelerin göç edilen ülkede ne tür savunmasızlıklara maruz kalabileceklerini bilememeleri gelmektedir.

\subsubsection{Göçmen Ailelerle İlgili Yaptsal Faktörler}

Yapısal faktörlerde göçmen aileler ile ilgili en fazla ele alınan konu aile birleşimidir. Ailelerin Birleşim Hakkı, 1989 Birleşmiş Milletler Çocuk Hakları Sözleşmesi (özellikle Madde 9) ve 1990 Tüm Göçmen İşçilerin ve Üyelerinin Haklarının Korunmasına İlişkin Uluslararası Sözleşmesi'nde yer bulmuştur.

Aile birleşimleri: Rapor analizlerine göre, demokrasilerde aile birleşimleri kapsamında ailelere kalıcı ikamet izni verilmesi ve temel hak ve hizmetlere erişim konusunda göç yönetim politikalarının iyi belirlenmesi gerektiği, aksi takdirde ev sahibi toplumlarda göçmen topluluklarına yönelik marjinalleştirme tutumlarının olabileceği yer almaktadır. Bir diğer bilgi ise çocuk ve genç nüfusun aile birleşimi kapsamında hedef ülkeye geldiklerinde bile aile birleşimini kendi istekleriyle reddettikleri ve yalnız hayat sürdürmeye çalıştıklarıdır. $\mathrm{Bu}$ nedenle ülkenin yaşam koşullarını bilen göçmenler, ailelerinin yanında kalmak yerine kendi tercih ettikleri yerlerde yaşamakta ve yeni geldikleri ülke kurallarını bilememekten kaynaklanan savunmasızlıklar yaşayabilmektedir.

Politik engeller: Göçmenlerin önemli kısmı aile birleşimine başvurmak istememektedir. Bunun nedenleri de birleşim yapılan ülke otoriteleri tarafından aileye duyulan güvensizlikler ve politik engellerdir. Politik engeller kapsamında göç raporlarında yapılan kodlamalarda, ülkeye girişte dil yeterlilik sınavının yapılması, ailenin ev sahibi topluma entegre olmasını sağlamayı amaçlayan aile birleşimi koşullarının sağlanamaması ve gelecek olan ailenin ülkede sponsorunun olup olmadığının tespit edilmesi gibi durumlardan bahsedilebilir. $\mathrm{Bu}$ durumların aile birleşimini ve ülkeye giren yabancıların sayısını sınırlandırdığı görülmektedir. Yıllara göre aile birleşimi ile ilgili kodlamalara bakıldığında bu durum ile ilgili küresel bir uygulamanın olmadığı ve saha uygulamalarında problem yaşandığ görülmektedir.

\subsection{Göçmen Kadınlar}

Göçmen kadınların savunmasızlıklarına ilişkin 70 adet kodlama yapılmıştır. Analizlerde uluslararası göç olgusunun, etnik ve kültürel grup çeşitliliği içerdiği, özellikle kadınların kendi başlarına ya da aile reisi olarak göç hareketlerini gerçekleştirdikleri görülmüştür.

\subsubsection{Göçmen Kadınlarla İlgili Bireysel Faktörler}

Güven sorunları: Göç raporlarına göre kadın göçmenlerin yaşadığı savunmasızlıklardan biri güven eksikliğidir. Raporlarda yapılan analizlerde göçmen kadınlar için bireysel güvenlik ve çevre güvenliğinden emin olamama durumu söz konusudur. Kodlamalarda göçmen kadınların düşük ücretli, düzensiz ve potansiyel sömürücü işlerde, genellikle enformel sektörlerde çalışma ihtimalinin daha fazla olduğu bulgulanmıştır. 2015 yılında yayımlanan Göç Raporu'nda göçmen kadınların savunmasızlığına ilişkin yer alan tespit şu şekildedir:

"Gö̧̧ ve kentleşme genellikle toplumsal cinsiyet ilişkilerinde köklü değişiklikler içerirken, düşük gelirli yerleşim yerlerinde yaşayan ve düşük ücretli, güvensiz işlerde çalışan çok sayıda kadın için faydalar 


\author{
asgari düzeyde olabilir. Kadınların kentsel kayıt dışı sektörde \\ çalıştırılma olasılı̆̆ı erkeklerden daha fazladır."
}

Aile yaşamında kadının sorumlulukları: Çalışma hayatı dışında, kadınların aile yaşamındaki sorumlulukların önemli bir yük olduğu, aile ve arkadaşların desteğine sahip olmayan veya ulusal ve belediye destek hizmetlerine erişimi olmayan yeni göçmen kadınların savunmasızlığı önemli ölçüde arttığı yapılan analizlerden anlaşılmaktadır. Kadın göçmenlere özellikle menşe ülkelerinde ayrımcılık uygulandığı, eşi vefat etmiş ya da ailelerinden çeşitli nedenle ayrı düşmüş kadınların kırsal arazi veya miras talepleri reddedildiği için yoksullaştıkları ve göç kararı aldıkları görülmektedir. Bu durum ele alındığında kadınların toplumsal cinsiyet rollerine veya cinsiyete dayalı şiddette karşı savunmasız kaldıkları için göç kararı aldıkları söylenebilir. Ayrıca kadınların göç karakterine ilişkin yapılan kodlamalarda kadınların uluslararası göç yollarına erişimlerinin olmamasının özellikle kırsal alanda bulunan kadınların ilk önce şehirlere göç ederek kaynak arayışına girmelerine neden olduğu görülmüsştür. Kadınların mülkiyet haklarını güvence altına alamamaları durumu ise mülkiyet edinebilecekleri yerlere göç etmelerine neden olmaktadır.

Geride bırakılma: Raporlarda göçmen kadınların yanı sıra geride bırakılan kadınların savunmasızlıkları yer almakta, özellikle geride kalan kadının aile reisi rolü üstlendiği ve yoksulluğa karşı savunmasız kalabildiği anlaşılmaktadır. Kadınlar çocuk ve yaşlı bakımı ile ev idaresini üstlenmekte ve yeni zorluklarla başa çıkma sorumluluklarını taşımaktadır. Sosyal ve kültürel normlar, bilgiye erişim ve kurumsal sorunlar gibi faktörler, kadınların geride kalmışlık durumlarına uyum sağlamasına engel teşkil edebilmektedir.

İs hayatında kadın: Yapılan analizlerden kadın göçmenlerin çalışma yaşamında savunmasızlıklar yaşadığı anlaşılmaktadır. Bu kapsamda düşük ücret, barınma problemi, uzun çalışma saatleri, işverenlerin potansiyel suiistimali ve istismarı, sosyal izolasyon ve sosyal güvence eksikliği yapılan taramalarda tespit edilen kodlardır.

\title{
4.3.2. Göçmen Kadınlarla İlgili Ailesel Faktörler
}

Aile yapısı ve kültürel normlar: Aile gelenekleri, statü, kültürel uygulamalar ve dini inançlar kadınların göç hareketlerini ve göç kararlarını etkilemektedir. Aileyi öncelik alan kadınlar, kişisel ihtiyaçlarından çok hane halkının ihtiyaçlarına odaklanarak göç hareketlerini gerçekleştirmektedir. 2018 Göç Raporu'nda yer alan bir araştırmada kadınların göç kararı almasında aile yapısının önemli rol oynadığı bilgisine ulaşılmıştır. Aynı rapordaki bir başka araştırmada da ebeveynlerinden biri ya da ikisinin olmadığı durumlarda kadınların göç oranlarının daha yüksek olduğu tespit edilmiştir.

\subsubsection{Göçmen Kadınlarla İlgili Yapısal Faktörler}

İnsan ticareti: Araştırmada kadın göçmenler için en fazla savunmasızlık oluşturan kodlama, insan ticareti başlığı altında olmuştur. Yapılan kodlamalarda genellikle "kadın ve çocuklar" birlikte alınsa da kendi içlerinde farklılaşabilmektedir. Raporlarda yer alan bilgilere göre insan ticaretine yaş ve cinsiyet faktörleri etki etmektedir. İnsan ticareti siyasi arenada son yirmi yılda gündeme gelmişse de tarihi daha eskiye dayanmaktadır. İkinci Dünya Savaşı'nın sonunda, 1949 Birleşmiş Milletler İnsan Kaçakçıllı̆̆nın Önlenmesine İlişkin Sözleşme' de cinsel amaçlarla kadın ticaretinin uluslararası kapsamda önlenmesinin çerçeveleri net şekilde çizilmiştir. İnsan Ticareti kurbanlarının toplam sayısı cinsiyete ve sömürü biçimine göre ayrıştırıldığında, kadınların daha büyük bir kısmının cinsel istismara maruz kaldığı (Örneğin; 2014 yılında tespit edilen toplam kadın kurbanların\%72'sidir) görülebilmektedir. Yapılan 
kodlamalarda tacirlerin daha çok dijital platformları (sosyal medya vb.) kullandığı ve bu alanlarda mağduriyetler yaşandığı değerlendirilmiştir.

Fırsat eşitliği: Taramalarda istihdama erişim hakları, adil ücret dağılımı, temel hak ve hizmetlere erişim, geleceğe yönelik birikim planlamaları yapmak ve bu politikalara dahil olmak, kişisel güvenlik ve sosyal güvence eksiklikleri, siyasi temsilde cinsiyet eşitsizliği ve kentleşmeyle gelişen sosyal hizmetlerden yararlanamama durumları kadın göçmenlerin yaşamış olduğu yapısal savunmasızlıklar olarak belirlenmiştir.

Sosyal politika önerileri: Raporlarda kadın göçmenlerle ilgili sosyal politika önerilerine yer verilmiştir. Kadın göçmenlerin ya da mağdurların koruma kapasitelerinin arttırılması ile ilgili olarak koruma zincirinde bulunan kamu kurum ve kuruluşlarındaki yetkililerin (savc1, hâkim, polis, sınır güvenliği yetkilileri, iş güvenliği biriminde çalışanlar ve sosyal hizmet uzmanları) eğitiminin önemli olduğu vurgulanmaktadır. Ayrıca savunmasız kalan mağdur kadınlara yönelik yardım fonlarının harekete geçirilmesi gerektiği belirtilen bir diğer noktadır. Yapılan kodlamalarda özellikle menşe, transit ve hedef ülkelerde yaşanabilecek savunmasızlıklara karşı sivil toplum kuruluşlarının önemli roller alması gerektiğinin vurgulandığı görülmektedir. Özellikle savaş bölgelerinden gelen göçmen kadınlar için ücretsiz hukuki danışmanlık, akşamları yetişkin eğitimi ve travmatik deneyimler yaşayanlar için psiko-sosyal bakım gibi hizmetlerin sunulması gerekliliğine ilişkin öneriler analizlerde elde edilen diğer önemli sonuçlardır.

Göçmenlikte kırılganlık: Sivil toplum kuruluşları ve sosyal hizmet uzmanlarının karşılaştıkları güçlükler ve göçmenlerin hedef ülkede yaşadıkları sorunlarla ilgili makaleler de raporlarda yer almıştır. Bu makalelerin sonuçları ile yapılan kodlamalarda toplumsal cinsiyet ve özellikle kadın göçmenlerin karşılaştıkları problemlere, aynı zamanda ebeveynlik konularına ve gençlerin karşılaştığı özel entegrasyon ve aidiyet sorunlarına odaklanılmaktadır. Bu kapsamda özellikle göçmenlikte kırılganlık kavramı ön plana çıkmaktadır. Kırılganlığın en aza indirgenmesi için sağlık ve psikolojik danışmanlık hizmetlerinin, özellikle göçmen kadınlar, ergenler ve göç aşamalarındaki refakatsiz ya da terk edilmiş çocuklar için sağlanmasının önemli olduğu yapılan analizlerden anlaşılmaktadır.

İs birliği ve ortakllklar: İnsan ticareti mağdurlarına yönelik koruma, yardım, hizmet sunumu ve kapasite geliştirme konuları da dahil olacak şekilde, fiziksel ve psikolojik sağlık önlemlerinin bütünleştirilmesi gerekmektedir. Bu alanlara ilişkin politika ve uygulamaları uyumlu hale getirmek, sağlık ihtiyaçlarına yönelik bakım ve medikal hizmetlerin sürekliliğini sağlamak için sınır ötesi iş birliği ve ortaklıklar kurulması gerekliliği raporlarda vurgulanan önemli bir diğer bulgudur. Ylllara göre bakıldığında insan ticareti sorununun (özellikle seks işçiliği açısından), kadın göçmenler için devam eden bir sosyal problem olarak mevcudiyetini koruduğu görülmektedir.

\section{4. Çocuk Göçmenler}

Savunmasızlıklar kapsamında en fazla kodlanan kategori çocuk göçmenlerdir. Göç sürecinin tüm aşamalarında ve her boyutunda en fazla savunmasız olan grubun çocuklar olduğu söylenebilir. Çocuklarla ilgili olarak göç raporlarında 104 adet kodlama gerçekleştirilmiştir.

\subsection{1. Çocuk Göçmenlerle İlgili Bireysel Faktörler}

Göç raporlarından elde edilen veriler kapsamında, çocuk göçlerinin genel olarak aile birleşimi şeklinde gerçekleştiğinin düşünülmesine rağmen çocukların önemli bir kısmının bağımsız göç hareketi yaptıkları da görülmektedir. 
Geride bırakılma: Önceki başlıklarda değinilen geride bırakılma ile ilişkili savunmasızlık durumu çocuklar için de söz konusudur. Geride kalan çocukların da kaldıkları bölgenin durumuna göre çeşitli savunmasızlıklar yaşadığı anlaşılmaktadır. Bir diğer tespit edilen durum da ailenin çocuk üzerindeki etkisidir. Aile dinamiklerinin göçün itici faktörlerinden olabileceği, ailede kayıpların yaşanması (aile reisi ya da geçimi sağlayan kişinin kaybı) ve ailenin ekonomik kazanç elde etme çabası çocukları göç olgusuna sürükleyen nedenler olarak görülmektedir. Ayrıca, raporlarda, geride kalmış çocuklarda anksiyete, depresyon, intihar düşüncesi, madde bağımlılığı ve büyüme bozuklukları riskinde artış gibi sorunların olduğu bilgilerine yer verilmiştir.

Hak ve hizmetlere erişim: : Yapılan analizde şiddete karşı savunmasız kalan çocukların yanı sıra bulundukları ülkede eğitim, sağlık ve diğer hak ve hizmetlere ulaşamayan çocukların da göç etmek zorunda kaldıkları tespit edilmiştir. Örneğin, 2018 Göç Raporu'nda yer alan bir araştırmaya göre Afgan göçmen çocukların göç sebepleri "yoksulluk, güvensizlik, yetersiz eğitim koşulları" olarak belirlenmiştir.

Refakatsizlik: Çocuk göçmenler açısından taramalarda elde edilen bir diğer savunmasızlık durumu refakatsizliktir. Raporlarda özellikle refakatsiz çocukların kayıplarına dikkat çekilmektedir. Göç yolculuğu boyunca savunmasız kalan refakatsiz çocukların ihmal ve istismarının daha kolay olduğu, göç sonrası travma risklerinin bulunduğu, hedef ülkede vesayet ve yasal temsile erişim konularında çocukların sıkıntılar yaşadığı belirtilmiştir.

Statü belirsizliği: Çocuk göçmenleri savunmasız duruma düşüren bir diğer faktör statü belirsizliğidir. Sı ğınma başvurusu reddedilen çocukların statülerinin düzensiz duruma düşmesi ve bu durumla ilişkili temel hak ve hizmetlere erişimlerinde kısıtlamaların olması durumu kodlamalarda sık karşılaşılan bir durum olarak belirlenmiştir.

Sayısal artıs ve gündem olma: Raporlarda göçmen çocuklar ile ilgili yapılan kodlamalarda yıllara göre artış olduğu ve bu konuda önemli değerlendirmelere yer verildiği görülmüştür. Özellikle 2020 Göç Raporu çocuk göçmenlere dair en kapsamlı bilgi aktarımının yapıldığı doküman niteliğini taşımaktadır. Yine aynı raporda yer alan ve 2019'da yapılan bir araştırmada 20 yaşının altında 37,9 milyon göçmen bulunduğu, bu sayının tüm göçmenlerin \%14'ünü oluşturduğu, UNICEF'in 2016 yılında yayınlamış olduğu raporda her 45 çocuktan 1 'inin göç hareketinde bulunduğu, Afrika ülkelerinde her beş kişiden 1 'inin 20 yaş altında çocuk olma özelliği taşıdığı vurgulanmaktadır. Raporlarda yapılan analizlerde çocuk göçünün gündemde tutulmasının nedeninin, çocuk göçmenlerin savunmasızlığının haber değeri taşıması şeklinde olduğu tespit edilmiştir.

Barınma merkezleri: Göçmen çocuklar için raporlarda yer alan bir diğer savunmasızlık durumu da geçici barınma merkezlerinde (mülteci kampları) yaşanılan sorunlardır. Kamplarda eğitim eksiklikleri, göçmen çocukların cinsel istismar riskinde artış olması, psiko-sosyal destek ve temel sağlık hizmetlerine ilişkin mekanizmalarının yetersiz oluşu başlıca savunmasızlık durumları olarak tespit edilmiştir.

Risk ve tehdit unsurları: Sömürü ve istismar riski, idari gözetime alınmanın olumsuz etkisi, aileden ayrılmanın etkisi, sağlık hizmetlerine ve eğitim imkanlarına yetersiz erişim, zorunlu çocuk göçünün itici güçlerine dikkat edilmemesi ve son olarak da ayrımcılık konusu çocuk göçmenler için risk ve tehdit oluşturan başlica durumlar olarak tespit edilmiştir. Ayrıca refakatsiz çocukların sınır dışı edilmesi oldukça önemli bir risk durumu oluşturmaktadır. İstatistiksel olarak çocuk göçmen rakamları ile ilgili tutarlılığın olmadığı ve biyometrik göstergeler kapsamında çocukların bilgilerinin kayıt altına alınmasının gizlilik ihlali yaratabileceği yapılan analizlerden anlaşılmaktadır. Bu nedenle gizliliğe riayet edilerek veri güvenliğine dikkat edilmesinin gerekliliği vurgulanmaktadır. Ayrıca son dönemde sıklıkla 
medya gündeminde olan, çocukların boğularak hayatlarını kaybetmesi durumu ile ilgili olarak göç seyahatleri sırasında çocukların boğulmalara ya da ölümcül düzeyde dehidrasyona maruz kaldıkları raporlarda da yer almaktadır. Özellikle menşe ülkede yaşanan zulüm, çocukları zorla askere alma ya da çocuklara silah kullandırma, çocuk istismarı, çocuk evliliği gibi savunmasızlık durumları göç hareketine neden olmaktadır. Bulgularda göç eden çocukların çoğunun ailelerinin bir parçası olarak güvenli göç süreçlerinden geçtiği bilinirken, birçok çocuk göçmenin de refakatsiz olarak göç hareketini gerçekleştirdiği görülmüştür. Çocuklardan bazıları, menşe ülkede, transit bölgelerde, geçici veya kalıcı varış yerlerine ulaştıklarında ya da denizlerden geçerken yolculuklarının tüm aşamalarında risklere karşı etkili korunmadan yoksun olmaya ve sürekli insan hakları ihlallerine maruz kalmaya devam etmektedir.

\subsection{2. Çocuk Göçmenlerle İlgili Toplumsal Faktörler}

Damgalanma: Toplumsal faktörlere ilişkin savunmasızlık durumları kapsamında yapılan kodlamalarda ikamet süresine bakılmaksızın illegal olan göçmen çocukların çevresel baskı hissettikleri ve damgalama yaşadıkları görülmektedir. Dini inanç ayrımcılığına ve 1rkçılığa da maruz kalan göçmen çocuklar toplumsal mekanizmalara karşı savunmasız kalabilmektedirler.

\subsection{3. Çocuk Göçmenlerle İlgili Yapısal Faktörler}

Insan ticareti: Göçmen kadınlarda olduğu gibi, göçmen çocuklarda da insan ticareti mağdurluğu öne çıkmaktadır. Sınırdışı edilen, ülke içinde yerinden edilen, göçün her safhasında savunmasız hale gelerek ihmale ve istismar edilmeye açık hale gelen çocukların insan ticaretine maruz kaldıkları yapılan analizlerde görülebilmektedir. Göç raporlarında çocuk göçmenlerin korunmaları noktasında önemli boşluklar olduğu sıklıkla vurgulanmaktadır. 2020 Göç Raporu'na göre Avrupa Birliği üyeleri tarafindan yapılan açıklamalarda insan ticaretinde çocukların oranında \%23'lük artış gözlemlenmiştir.

İstismar ve sömürü riski: Çocukların ağır istismar ve sömürüye maruz kalması ve çatışma ve iç karışıklık yaşanan ülkelerde ordu ya da diğer silahlı gruplar tarafından asker olarak kullanılmaları ile ilgili durumlara bakıldığında, özellikle çocuk göçmenlerin hem çocuk hem de göçmen olarak çift yönlü savunmasızlığı söz konusudur. Zorla çalıştırılma ve erken yaşta evlilikler çocukların savunmasız olduğu en şiddetli sömürü biçimi olarak raporlarda yer almaktadır. Yapılan analizlerde, çocuk göçmenlerin istismar ve sömürüye karşı savunmasızlıklarının güvenli olmayan, düzensiz ve sömürü içeren göç hareketlerinden kaynaklandığı tespit edilmiştir. Sömürüye dayalı göçte, cinsiyet farklılıkları göç hareketlerini etkileyebilmektedir. Kız çocukların seks işçiliğinde çalıştırılmak üzere göç hareketlerini gerçekleştirdikleri görülebilmektedir. Ayrıca çocukların tek başlarına göç ederken ya da göç yolunda ailelerinden ayrıldıklarında, şiddet ve insan ticaretine maruz kalma riskleri artmaktadir.

Sosyal problemler: Göçmen çocukların korunması noktasında birçok boyutta sosyal problemlerin olduğu görülebilmektedir. Araştırmada resmi mekanizmaların uygulamalarındaki yanlışlıklar (çocukların idari gözetim altına alınmaları ve göç mevzuatının uygulanmasına ilişkin problemler), toplumsal davranışlar (yabancı düşmanlığ ve saldırıların olması gibi), işverenlerin sömürüsü (çocuk işçiliği mesleklerine göre farklılaşabilir) ve diğer çocuklardan gördükleri muameleler (zorbalık ve okulda dişlanma vb.) raporlarda karşılaşılan sosyal problemlerden en fazla kodlananlardır. IOM raporlarına göre çocuk ölümlerindeki artış, göçe katılan çocukların koruma ve destek sorunsalı için önemli bir konudur. Bu konu ile ilgili olarak 2018 Göç Raporu'nda verilen bir durum tespiti şu şekildedir: 
"IOM'un Kayıp Göçmenler Projesine göre, 2000 yılından bu yana en az 46.000 göçmen ölümü gerçekleşmiş̧ ve ölenlerin çoğunun çocuk olduğu bilgisine ulaşllmiştır. Örneğin 2015 yllında IOM, Ege Denizi'ndeki her üç göçmen ölümünden birinin çocuk olduğunu tahmin etmektedir. Ayrica, Mayls ve Aralı 2015 arasinda Akdeniz'de Sinır Tanimayan Doktorlar (Médecins San Frontières) tarafindan denizde kurtarılan yaklaşı 24.000 göçmenin dörtte birinin çocuk olduğu açıklaması yapılmıştır."

Korunma ihtiyacı: Analizlerde çocuk göçmenlerin korunması noktasında göç hareketlerinin taşıdığı riskler ve göçmen çocukların korunması ile ilgili yönetimsel uyumsuzluklar görülmektedir. Bu durum, mevcut göç problemleri ile çözüm politikalarının uyuşmaması olarak değerlendirilmelidir. Yapılan taramalarda, acil korumaya ihtiyaç duyan savunmasız nüfuslar için planlamaların olmaması, bu nüfusun haklarının ve can güvenliğinin sağlanması noktasında mağduriyetler yaratabilmektedir. Analizlerde tespit edilen bir diğer nokta da korumaya muhtaç göçmen çocukların resmî kurumlara verilmeyerek göçmenler arasında özel ve izinsiz oluşturulan barınma yerlerinde ikamet etmeleri ve istismara karşı korunmasız kalmalarıdır. Ayrıca raporlarda göçmen çocuklara ilişkin yetişkinliğe geçiş eğitimi, koruma ve destek hizmetleri ile ilgili politika ve uygulamaların eksik olması nedeniyle ruh sağlığı çalışmaları ve refah iyileştirmelerinin yetersiz olduğu bilgisine ulaşılmıştır.

Cocuk politikaları: Yıllara göre çocuk koruma politikaları ile ilgili kodlamalar mevcudiyetini korumaktadır. Kodlamalarda ulusal düzeyde göç yönetiminde çocukların korunması ile ilgili sorun yaşayan devletlerin, bu konuda sınır ötesi operasyonlarda yetersiz kaldığ1 değerlendirilmiştir. Göçmen çocukların korunması ve desteklenmesi kapsamında göç raporlarından elde edilen kodlardan genel bir tespit yapılmak istenirse, çocuk göçmenlerin temel insani ihtiyaçlara, temel hak ve hizmetlere ulaşmalarına ilişkin çalışmaların yeterli olmadığı, bu konuyla ilgili olarak koruma sorunsalına ilişkin planlamaların ve araştırmaların çocuk odaklı yapılması gerektiği ve bu eylemlerin bir an önce yapılmasının gerekliliği vurgulanmaktadır.

İdari gözetim tedbirleri: İdari gözetim tedbirlerinin çocuk göçmenlere uygulanması raporlar üzerinde yapılan kodlamalarda bir başka savunmasızlık durumu olarak tespit edilmiştir. Yasadışı yollarla ülke sınırlarına giren çocukların sınır dışına gönderilmek üzere idari gözetime tabi tutulmaları ve çocukların yüksek yararını gözetmeyen uygulamaların varlığının çocuk göçmenlerde travmatik etki yarattı̆̆ anlaşılmaktadır. Geri Gönderme Merkezlerinde ya da idari gözetim uygulanan başka yerlerde güvenlik ve çocuk koruma garantilerinin bulunmaması raporlarda yer alan bir diğer endişe verici durumdur. Çocukların idari gözetim altında iken acil ve karşılanmamış uluslararası koruma gereksinimlerinin giderilmesine ilişkin vurgular yer almaktadır.

Doğal afetler ve iklim değişikliği: İklim değişikliği nedeniyle meydana gelen hareketlilikte göçmen çocukların ve ailelerinin etkilendiği analizlerde tespit edilmiştir. Ayrıca yapılan kodlamaların frekans sıklığına bakıldığında, göç hareketliliği bağlamında çocukların karar verme mekanizmalarının eksik ve yetersiz olması ile birlikte ülkelerinin acil eylem planlamalarında koruma prosedürlerinin yeterince yer almadığı anlaşılmıştır. Özellikle meydana gelen doğal afetlerde ya da iklim değişikliklerinde kayıp vakalarının artması buna bağlanmaktadır.

Sosyal politika önerileri: Son olarak çocuk göçmenler ile ilgili olarak sosyal politika gereksinimleri ve önerilerinden bahsedilebilir. İlk olarak insan ticareti mağduru, yerinden edilmiş ya da sınır dışı edilerek ülkesine geri gönderilmiş çocuklar için danışmanlık ve 
eğitim faaliyetlerinin yapılması gerekliliği raporlarda vurgulanmaktadır. Bununla birlikte aile ve toplum sağlığı kapsamında anne-çocuk sağlık hizmetlerinin sunumunda dil sorunun çözülmesi gerektiği anlaşılmaktadır. Çocuk göçmenlerin statü belirsizliğinin giderilerek temel hak ve hizmetlere ulaşımlarının sağlanması, yasal statülerine bakılmaksızın her çocuğa ilk olarak eğitim imkanları olacak şekilde, kamu hizmetlerine erişimlerine ilişkin gerekli yasal düzenlemelerin yapılması ve uygulamalarının eksiksiz gerçekleştirilmesi gerektiği yapılan incelemelerden elde edilen bir diğer önemli sonuçtur. Yapılan analizlerde özellikle de eğitim ile ilgili kodların sıklığı görülebilmektedir. Eğitime ilişkin 2020 Göç Raporu'nda şu şekilde bir ifade vardır:
"Devletler, kendi yetki alanlarındaki tüm çocuklara ayrım gözetmeksizin eğitim să̆lamakla yükümlüdür. Ĕgitim, sadece bireysel beceriler ve iş piyasasına erişim ile ilgili değildir. Aynı zamanda sosyal içerme, akran grubu karşılaşmaları, yeni kültür ve dil edinimi konuları da eğitimin içeriğinde bulunmalıdır. Farklı pedagojik ve duygusal ihtiyaçlara yanıt veren güçlü çok kültürlü ortamlar oluşturmaya yönelik yenilikçi eğitim hizmetlerinin birçok örneği mevcuttur."

Rapor analizlerinde refakatsiz çocukların göç ettiği ülkelerde vesayet programları ve ücretsiz yasal temsil hizmetlerinin yapılandırılması, politika uygulamalarının eksik veya tutarsız olduğu durumlar ile ilgili olarak çocuk göçmenler için uygulanması gereken asgari standartlar konusunda çocukların yüksek yararının gözetilmesi, çocuk göçmenlerin idari gözetim altına alınmaması, çocuk göçmenlerin suça sürüklenmeleri ile ilgili savunmasızlıkları ve bağımlılıkları konusunda çalışmalar yapılması, göçmen çocukların ev içi eğitime entegre edilmesinin gerekliliği, çocuk koruma hizmetleri ile refakatsiz ve ailelerinden ayrı düşmüş çocuklara özel tedbirler uygulanması, çocuk gelişimi ve refahı için meslek uzmanlarının programlarına ve eğitimlerine, çocuk ve göç ile ilgili özel hususların kademeli olarak dahil edilmesinin gerekliliği anlaşılmıştır. Bununla birlikte savunmasız çocuk göçmenlerin erken tespitini ve gerektiğinde acil durum desteğinin sağlanmasının yanı sıra, uygun olduğunda yeniden entegrasyona yardımcı olmak için göç, aile ve toplum destek mekanizmalarının kurgulanması, raporlarda yer alan bir diğer husustur.

\section{Tartışma}

Araştırmamızda, IOM tarafından yıllık olarak yayınlanan göç raporlarında savunmasız grupların durum tespiti, yaşadıkları sorunlar ve yıllara göre sorunların devam edip etmediği ile ilgili olarak tespitler ve analizler yapılmaya çalışılmıştır. Bu kapsamında IOM tarafından belirlenen savunmasız gruplara yönelik sınıflandırma temel alınmış ve buna göre kodlamalar yapılmıştır. IOM tarafından yapılan modellemede savunmasız grupların bireysel, ailesel, toplumsal ve yapısal olarak dört boyutta mağduriyetler yaşadıkları belirtilmektedir. Yapılan analizde savunmasız grupların geneline yönelik değerlendirmeler ve kadın, aile ve çocuk kategorileri üzerinden değerlendirmeler yapılmaya çalışılmıştır. Göçmenlerin karşılaştığ savunmasız durumlar, eşzamanlı ortaya çıkan veya iç içe geçmiş, birbirlerini etkileyen, şiddetlendiren ve koşullar değiştikçe zamanla gelişen veya değişen bir dizi faktörden kaynaklanabilir (UNHOC, 2018). Örneğin bir göçmen kadının daha iyi hak ve hizmetler arayış çabası için göç kararı alması bireysel faktör olabilirken; gittiği hedef ülkede göçmen kadınlar ile ilgili koruma yasalarının olmaması yapısal faktör olarak değerlendirilebilir.

Araştırma bulgularına göre hassas gruplar ile ilgili olarak başlıca savunmasızlık yaratan durumlar; istihdam alanında yaşanan sorunlar ve sömürüler, yasal statü belirsizlikleri, işsizlik ve ani gelişen durumlarla yaşanan iş kayıpları, yasa dışı kalışların beraberinde getirdiği riskler, göçün gerçekleşme koşullarının yada itici faktörlerinin travmatik sonuçları, 
güvenlik, eğitim ve sağlık gibi temel insani ihtiyaçların sağlanamaması şeklindedir ve göçmenlerin mağduriyet yaşamalarına neden olmaktadır. Bununla beraber uyum problemlerinin yaşanması toplumsal düzeyde göçmenleri etkilemektedir. Ayrıca sosyal güvence eksikliği, temel sağlık hizmetlerine erişimdeki uygulamadan kaynaklı problemler göçmenleri savunmasız kılan diğer sorunlardır. LGBTIQ+ göçmenlerin travmatik stres bozuklukları yaşamaları da raporlarda sıklıkla karşılaşılan bir durum olarak dikkat çekmektedir. Ailesel faktörlerle ilgili olarak göçmen ailelerin çeşitli sosyo-ekonomik durumlardan dolayı yaşam kalitelerinin düşmesi ve aile birleşimlerinin yapılmasına yönelik gerekli düzenleme ve çalışmaların olmaması ya da politik engellerin olması da savunmasızlığı meydana getiren durumlar olarak değerlendirilmiştir. Savunmasız grupların tüm düzeylerde karşılaştığı durum ise yasal düzenleme eksikliklerinden kaynaklanan statü belirsizliği ve insan ticaretidir. İnsan ticareti ve statü belirsizlikleri bütün göç raporlarında yer almakla birlikte y1llara göre ciddiyetlerini arttırarak süreğenliğini koruyan sorunlar olarak ele alınmaktadır. Statü belirsizliği beraberinde temel hak ve hizmetlere erişimde sinırlılıklar ya da engeller oluşturabilmektedir. Göçmen kadınlar ile ilgili olarak güvensiz çevre ve güven problemi, aile içindeki statü kayıplarının olması, cinsiyete dayalı şiddete maruz kalma, iş piyasası ile ilgili sömürü ve istismar, seks işçiliğine zorlanma, göçmenlikte kırılgan bir yapı olarak yaşamını sürdürme gibi problemler savunmasızlıkları arttırabilecek faktörler olarak değerlendirilmiştir. Zorunlu göçün dezavantajlı gruplar içerisinde belki de her koşulda savunmasız grubu tartışmasız çocuklardır. Çocuklar iradeleri dikkate alınmaksızın, ebeveynlerinin kararlarını yerine getirmek zorunda kalarak göç sürecinin bir parçası olmaktadır (Göktuna ve Sirkeci, 2019: 135). Göçmen çocuklarda refakatsizlik, aileden mahrum bırakılma, göç evrelerinde ihmal ve istismara uğrama, hedef ülkede toplum tarafından baskı altında kalma ve damgalanma, göç sonrası travma riski, göç evreleri boyunca aktif ve koordineli çocuk koruma sistemlerinin olmaması, idari gözetim altına alınma, eğitim hizmetlerine ulaşmada yasal engeller, statü belirsizliği, istismar ve sömürüye maruz kalma ve insan ticareti mağdurluğu mağduriyet yaşatacak problemlerin başında gelmektedir.

\section{Sonuç}

Göç krizleri geçmişten bugüne devam eden bir olgudur. Sosyal hizmet uygulamaları göç alanında önemli bir yer tutmaktadır. Savaşlar, iç karışıklıklar ve politik anlaşmazlıkların doğurduğu insani tablolar sosyal hizmet müdahaleleri gerektiren sorunlardır. İklim değişikliği ve doğal felaketlerin meydana gelmesi de sosyal hizmet mesleğinde kriz sosyal hizmeti olarak yerini almaktadır (IASSW, 2016). Yaşadıkları savunmasızlıklardan dolayı mağdur duruma düşmüş göçmenlerle klinik sosyal hizmet çalışmalarını yürütmek için hizmet boyutlarını bilmekte yarar vardır. Alanda çalışan sosyal hizmet uzmanının ilk olarak bilmesi gerekenler, başvuru sahibini geçmişte göçe iten faktörler (politik, toplumsal cinsiyet, marjinal grup, vb.) ve yaşadığı travmatik deneyimlerdir. İkinci olarak her bireye yönelik müdahalelerin farklı olabileceği bilinmelidir. Sosyal hizmet uzmanları bilgi, beceri ve değerlerini eklektik bir şekilde kullanarak ve kurumlarla iş birliği içerisine girerek müdahale planı oluşturmalıdır. Üçüncü olarak meslek elemanları bireysel ve ailesel dinamiklerin yanında mensup olunan din ve kültürel yapıları da müdahale odağında tutmalıdır. Dördüncü olarak da göçmenlerin yeni topluma uyum süreçleri ve karşılaşmış oldukları sorunlar ile ilgili baş etme mekanizmalarının oluşturulması gerekmektedir (Bowles, 2015).

Sosyal hizmet uzmanlarının göç süreçlerinde yaşanan travmalar, kayıplar ve maruz kalınan işkence ve mağduriyetlerle ilgili danışmanlık yapmak, statü belirsizliği kapsamında oluşabilecek savunmasızlıkları gidermek için psiko-sosyal ihtiyaçları gidermek, temel hak ve hizmetlere erişimlerini sağlamak üzere göçmenlerin savunuculuğunu yapmak, güçlendirme 
temelli psiko-sosyal değerlendirmeleri yapmak gibi önemli rolleri bulunmaktadır. Bunun yanında güvenli yaşam ve sosyal bütünleşmeye yönelik olarak güçlendirme çalışmalarının yapılması gerekmektedir. Araştırma, sosyal hizmetin de aralarında bulunduğu farklı disiplinlerden göç alanı uygulayıcılarına ve konu ile ilgili sosyal politika içeriklerine yönelik olarak, savunmasız göçmenlere ilişkin genel çerçeveyi sunmaktadır. Ayrıca konunun önemini ve gerekliliklerini ortaya koyarak, göçmenlik ve savunmasızlık olgusunu farklı boyutlarıyla ele alacak yeni araştırmalara da aracılık edecektir.

\section{Araştırmaya İlişsin Etik Bilgiler}

$\mathrm{Bu}$ araştırmanın verilerini IOM tarafından erişime açık olan raporlar oluşturmaktadır ve söz konusu raporlara IOM'un resmî web sitesi üzerinden online olarak erişilmiştir. İnsan ve hayvanlar üzerinde yapılan bilimsel araştırmalarda etik kurul izni gerektiğinden ve bu araştırmanın verilerini erişime açık yazılı kaynaklar oluşturduğundan etik kurul iznine ihtiyaç duyulmamıştır. 


\section{Kaynakça}

AKGÜN, E. (2016). Modern Kölelik İnsan Ticareti ve Rakamlarla Türkiye Gerçeği. Marmara Üniversitesi Hukuk Fakültesi Hukuk Araştırmaları Dergisi, 22(1), 157-182.

BRULE, N., ECKSTEIN, J. J.(2017). Vulnerable Groups, (Ed. Mike Ellen). The SAGE Encyclopedia of Communication Research Methods.Thousand Oaks, SAGE Publications, 1871-1874.

BOWEN, G. (2009).Document analysis as a qualitative research method. Qualitative Research Journal, 9(2), 27-40.

BOWLES, R. (2015). Social Work With Refugee Survivors Of Torture And Trauma, Social work in the Service for the Treatment and Rehabilitation of Torture and Trauma Survivors, Erişim Adresi:http://www.startts.org.au/media/Research-Doc-Social-Workwith-Refugee-Survivors-of-Torture-and-Trauma.pdf.(Erişim: 20.03.2021).

DEROSE, K.P., ESCARCE, J.J., LURIE, N. (2007). Immigrants and health care: Sources of vulnerability. Health Affairs, 26(5), 1258-1268. doi:10.1377/hlthaff.26.5.1258

FARKAS, K. J., ROMANIUK, R. J. (2020). Social work, ethics and vulnerable groups in the time of coronavirus and Covid-19, Society Register, 4(2), 67-82 Erişim Tarihi: 25.02.2021, Erişim Adresi: https://case.edu/socialwork/about/newspublications/farkas-and-romaniuk-pen-article-social-work-ethics-and-vulnerablegroups-time-covid-19

GÖKTUNA, Y.F., SİRKECİ, İ.(2019). Sunuş: Göç Ülkesi Türkiye'de Sosyal Hizmet., Kuramsal ve Uygulama Boyutları ile Türkiye'de Sığınmacı, Mülteci ve Göçmenlerle Sosyal Hizmetler. Londra: Transnational Press London.

SAHA, A. (2019). Vulnerability and vulnerable groups of people. The Palgrave Encyclopedia of Global Security Studies, 3(2), 1-7.

INTERNATIONAL ASSOCATION OF SCHOOLS OF SOCIAL WORK (2016). Refugees and Displaced Persons: The Role Of Social Work, Common Statement World Social Work Day 2016, Geneva.

INTERNATIONAL ORGANIZATION OF MIGRATION TÜRKIYE, (2020). IOM Resmi Web Sitesi, Erişim Tarihi: 05.12.2020, Erişim Adresi: https://turkey.iom.int/tr/iomturkiye-hakkinda.

INTERNATIONAL ORGANIZATION OF MIGRATION, (2019), Handbook on Protection and Assitance for Migrants Vulnerable to Violence, Exploitation an dAbuse, İsveç.

INTERNATIONAL ORGANIZATION OF MIGRATION, (2018). Reducing Vulnerabilities And Empowering Migrants, Regional Office for East and Horn of Africa, Nairobi.

KARATAŞ, M. (2020). Kitlesel Göç, Sosyal Kabullenme ve Uyum Bağlamında Türkmen İş̧̧ilerin Çalışma Deneyimleri. Ankara Üniversitesi, Sağlık Bilimleri Enstitüsü, Doktora tezi.

KIRAL, B. (2020). Nitel bir veri analizi yöntemi olarak doküman analizi . Siirt Üniversitesi Sosyal Bilimler Enstitüsü Dergisi , 8 (15) , 170-189.

MIGRATION DATA PORTAL(2020). Web Sitesi, Erişim Tarihi: 05.12.2020, Erişim Adresi: https://migrationdataportal.org/themes/human-trafficking. 
ÖZKAN, U.B. (2020).Eğitim Bilimleri Araştırmaları İçin Doküman İnceleme Yöntemi, 3. Bask1, Ankara, Pegem Akademi.

ROESTENBURG, W. (2012). A social work Practice perspective on migration, Social Work/Maatskaplike Werk, 48(1), 1-17

SONER, G., AYDIN-AVCİ, İ.(2019). Savunmasız gruplar, risk yönetimi ve halk sağlığ1 hemşiresinin rolü . Samsun Sağlık Bilimleri Dergisi , 4 (1) , 14-22 .

YAVUZ, Y.(2019). Suç Mağduru Olma Korkusuna Sosyolojik Bir Bakış. Toplum ve Kültür Araştırmaları Dergisi, (4), 28-52.

UNITED NATIONS HUMAN RIGHTS OFFICE OF THE HIGH COMMISIONER, (2018).Principles and Guidelines, Supported By Practical Guidance, On The Human RightsProtectionOf Migrantsin Vulnerable Situations.

USMAN, M.U. (2014). Trafficking in women and children as vulnerable groups: Talking through theories of international relations, European Scientific Journa, 10(17), 282292. 